Development of Hybrid Manufacturing Technology for

Net-Shape Production of Monolithic Structures

A Thesis

Presented to

The Faculty of the Graduate School

At the University of Missouri-Columbia

In Partial Fulfillment

of the Requirements for the Degree

Master of Science

By

Mohamed Aly

Dr. Ahmed Sherif El-Gizawy, Thesis Supervisor

May 2017 


\title{
Development of Hybrid Manufacturing Technology for Net-Shape Production of Monolithic Structures
}

\author{
Presented by \\ Mohamed Aly, \\ A candidate for the degree of \\ Master of Science \\ and here by certify that, in their opinion, it is worthy of acceptance.
}

Professor Sherif El-Gizawy

Associate Professor Matt Maschmann

Professor Hani Salim 


\section{ACKNOWLEDGEMENTS}

It is an honor and a pleasure to express my thanks and gratitude to my Advisor, Dr. Ahmed Sherif El-Gizawy, for giving me the opportunity to work with him. I would like to thank him for his invaluable encouragement, guidance, support and help throughout my master's research.

I also extend my sincere thanks to Dr. Matt Maschmann and Dr. Hani Salim for agreeing to serve as my thesis committee members.

I am forever indebted to my mother and father for the innumerable deal of sacrifices they have went through to further my education and opportunities, my mother for her continuous support throughout my study period and in general, and my grandmother for for having spent so much time and effort in helping of raising me.

This work was funded by the Industrial Technology Development Center at the University of Missouri, USA (ITDC). I, therefore, acknowledge the technical and financial support of ITDC. I wish also to acknowledge the experimental support of Engineering Technical Services at the University of Missouri. My appreciations are also extended to Mr. Edward Gerding, and Mr. Dick Lederich of the Boeing Company for their technical support, valuable discussions and encouragements. 


\section{Table of Contents}

ACKNOWLEDGEMENTS .ii

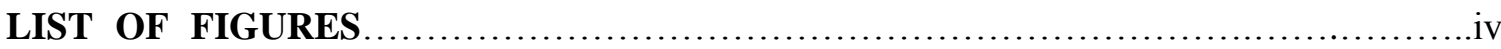

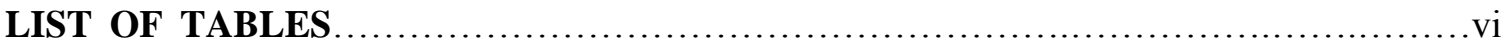

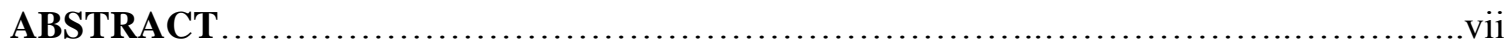

CHAPTER 1: INTRODUCTION........................................................................... 1

1.1 Statement of Problem............................................................................... 1

CHAPTER 2: LITERATURE REVIEW ................................................................... 2

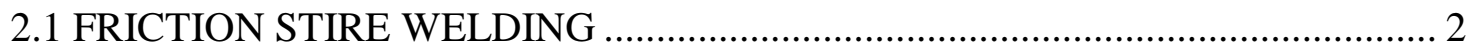

2.2 Process Parameters ...................................................................................... 3

2.3 STRETCH FORMING ............................................................................ 5

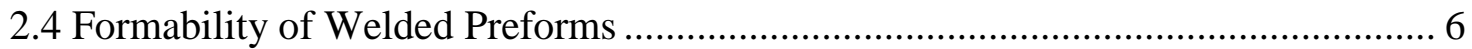

CHAPTER 3: EXPERIMENTAL INVESTIGATIONS ........................................... 7

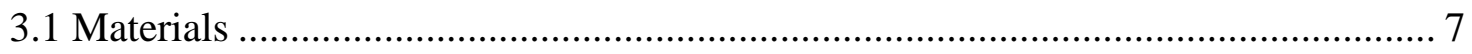

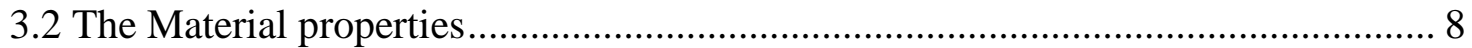

3.3 Experimental setup and Procedures ............................................................... 9

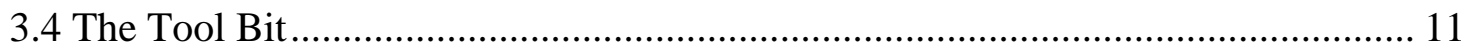

3.5 Friction Stir Welding Devices and Process .................................................. 12

3.6 Parametric Evaluation of Friction Stir Welding Process ................................... 14

3.6.1 Friction Stir Welding Similar Alloys ........................................................ 14

3.7 Friction Stir Welding Dissimilar Alloys ......................................................... 16

3.8 Stretch Forming of FSW Preforms ................................................................. 17

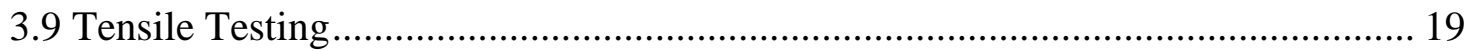

CHAPTER 4: RESULTS AND DISCUSSIONS ................................................. 22

4.1 Process-induced Properties of FSW Similar Alloys ......................................... 22

4.2 Process-induced Properties of FSW Dissimilar Alloys. ....................................... 25

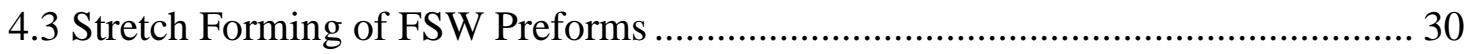

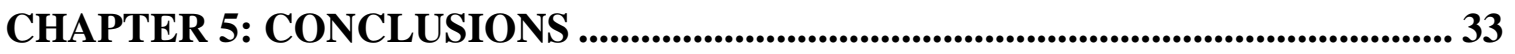

REFERENCES.............................................................................. 


\section{LIST OF FIGURES}

FIGURE 2.1 FrICTION STIR WELDING ProcESS....................................................... 4

FIGURE 2.2 STRETCH FORMING PROCESSES (A) STRETCH FORMING, (B) STRETCH DRAWING,

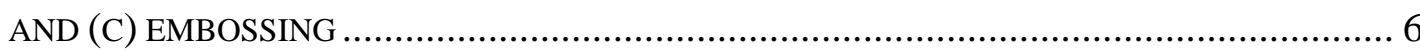

FIGURE 3.1 ASTM STANDARD TENSILE TEST SPECIMEN ….......................................... 8

Figure 3.2 Adapted Milling Machine for Friction Stir Welding Process ........... 10

Figure 3.3 Model of FinAl Design Of Friction StiR WeLding FiXTURE.................... 10

Figure 3.4 Close UP OF NEW ToOL BIT ................................................................... 12

FIGURE 3.5 FSW RIG WITH THE WELDED SHEET HOLDING FIXTURE ............................... 13

FIGURE 3.6 FSW RIG SHOWING THE TOOL AND PROCESS PASS ...................................... 13

FIGURE 3.7 MTS MACHINE WITH STRETCH FORMING FIXTURE.................................... 17

Figure 3.8 ToOL Set Up OF Stretch Forming ProceSS ......................................... 18

FIGURE 3.9 TAILOR WELDED BLANK SET UP ................................................................ 18

FIGURE 3.10 TENSILE TESTING SPECIMEN ............................................................... 19

Figure 3.11 HydRAULIC LiNEAR DisPlaCEMENT MACHINE WITH EXTENSOMETER ON THE

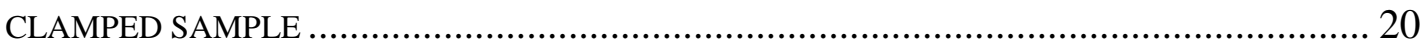

FIGURE 3.12 CLOSE UP OF EXTENSOMETER ........................................................... 21

FIGURE 4.1 SURFACE PLOT OF THE EFFECT OF WELD AND ROTATION VELOCITY ON

DUCTILITY OF FSW AL 2024-T3 WELDS. ........................................................... 24 
FIGURE 4.2 PROCESS CONTOUR MAP FOR DUCTILITY INDEX (\% ELONGATION) OF FSW AL 2024-T3 JOINTS 24

FIGURE 4.3 SURFACE PLOT OF THE EFFECT OF WELD AND ROTATION VELOCITY ON DUCTILITY OF BI-METALS AL 2024-T3/AL 7075-T6 WELDS. 26

FIGURE 4.4 PROCESS CONTOUR MAP FOR DUCTILITY INDEX (\% ELONGATION) OF BI-METALS AL2024-T3/AL 7075-T6 JOINTS. 27

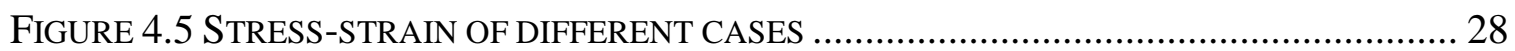

FIGURE 4.6 COMPARISON OF STRESS-STRAIN CURVES OF 2024, 7075 AND BI-A2 ............ 29

FIGURE 4.11 TAILORED WELDED PREFoRM BEFORE FormING ..................................... 30

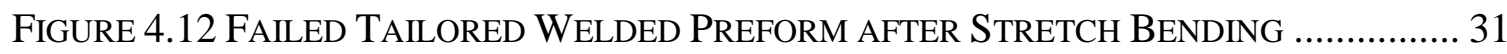

FIGURE 4.13 WELDED BLANK AFTER STRETCH FORMING …....................................... 31 


\section{LIST OF TABLES}

TABLE 3.1 Major Chemical Composition \% OF AL 7075-T6 ......................................... 7

TABle 3.2 Major Chemical Composition \% OF Al 2024-T3 …...................................... 7

TABLE 3.3 COMPARISON OF PROPERTIES OF AL 7075-T6 AND 2024-T3 …......................... 9

TABLE 3.4 EXPERIMENTAL LOG FOR FSW AL 2024-T3 WELDS ....................................... 14

TABLE 3.5 FIXED PROCESS PARAMETERS FOR FSW …………...................................... 15

TABLE 3.6 PROCESS PARAMETERS FOR FSW OF AL 7075-T6 .......................................... 15

TABLE 3.7 L9 ORTHOGONAL ARRAY FoR AL 7075-T6 \& Al 2024-T6............................... 16

Table 4.1 Mechanical Properties of Al 2024-T3 WeldS ........................................... 23

Table 4.2 Mechanical Properties of Al 7075-T6/Al 2024-T3 WeldS ...................... 26

TABLE 4.3 FormabILITY OF FSW AL 2024-T3/AL 7076-T6 STRUCTURES.......................... 32 


\begin{abstract}
The present work aims at exploring a new processing approach, 'Hybrid Manufacturing (HM)' technology for net-shape production of monolithic structures for the transportation industry. The HM process combines friction stir welding (FSW) and forming in order to modify the properties of the preform to better meet design requirements and provide netshape products. This paper focuses on understanding the process behavior and the effects of various process parameters on the properties and integrity of the produced monolithic structure during production. Formability of the produced monolithic structures is evaluated through stretch forming process experiments. The results obtained offer an understanding of the effects of the important process parameters needed to produce quality monolithic structures that fulfill design requirements and service conditions
\end{abstract}




\section{CHAPTER 1: INTRODUCTION}

This research aims at exploring a new processing approach, 'Hybrid Manufacturing (HM)', for net-shape production of monolithic structures for the transportation industry. The HM technology combines friction stir welding (FSW) and sheet metal forming in order to optimize the properties of the preform to better meet design requirements and provide net-shape products. HM can provide several advantages, reduced weight, part count reduction, improved damage tolerance, improved material and energy utilization, and cost savings ${ }^{1-3}$. The current work focuses on understanding the effects of various parameters on the properties and integrity of a structure produced using the HM processing approach.

\subsection{Statement of Problem}

There is little information available about the potentials and applications of the proposed approach. The effects of different FSW process designs on performance and formability of the preforms needs to be investigated. Properties and process-induced defects evolved during HM need to be characterized and managed using parametric investigation techniques. The present work focuses on exploratory and advanced development of HM for manufacturing large monolithic parts fabricated out of 2xxx and 7xxx series of aluminum alloys. It addresses material characterization, process-induced damage, process verification and identification of transition pathways. The proposed investigation will provide capability for robust processes, prediction and characterization of process-induced damage, and properties of the finished structure. 


\section{CHAPTER 2: LITERATURE REVIEW}

\subsection{FRICTION STIRE WELDING}

Friction stir Welding is a rather new technique, initially developed in 1991 by The Welding Institute (TWI) in Cambridge, England ${ }^{4}$ and has gradually grown in popularity since then. While many techniques exist for joining materials, the advantages of Friction Stir Welding is its ability to join dissimilar metals ${ }^{4}$ and that there is no phase change as witnessed by other welding techniques, with microstructural changes in the welded part as FSW involves no melting for the joining process.

Friction stir welding uses localized plastic deformation at the interface of the joint for establishing a bond between the base metals, shown in Figure 2.1. In the FSW process, the tool rotates and generates heat via interface friction and causes plastic deformation by extrusion at the

joint interface ${ }^{4-7}$. Unlike the commonly used fusion welding processes, the interface temperature during FSW always stays below the melting point of the base metals ${ }^{8}$. No liquid phase transformation takes place in FSW. This makes FSW a superior choice compared to other welding procedures that cause unfavorable microstructures and properties associated with solidification mechanisms in fusion welding. Furthermore, FSW operations have many other unique advantages: controlled properties, improved energy utilization, and is an environmentally clean process $^{5-7}$.

Friction Stir Welding is a good candidate for HM of monolithic structures because of its capability to weld alloys that are not typically weldable using traditional joining processes. This 
increased scope of joinable materials reduces restrictions on materials, which leads to an improved final product.

\subsection{Process Parameters}

FSW involves four stages: plunge stage (the rotating tool is plunged vertically into the joint); dwell stage (tool is held in the plunging position while still rotating); welding stage (rotating tool travels along the joint at a constant velocity); and pulling tool out stage (tool is pulled out of the joint leaving behind an exit hole). The parameters that influence the performance of FSW are displayed in Figure 2.1. They include tool rotational speed, travel speed of the tool, plunge force, plunge depth, and tool design ${ }^{5-16}$. These parameters affect the thermal and mechanical properties evolved during FSW. Numerous studies have examined FSW over a wide range of dissimilar materials ${ }^{15-22}$. Cavaliere et al ${ }^{16-17}$ investigated the mechanical and micro-structural properties of 2024-T3 and 7075-T6 aluminum sheets. Fatigue and stress analysis was performed using a weld velocity of $2.67 \mathrm{~mm} / \mathrm{s}$, however, the rotational velocity was not disclosed ${ }^{16}$. The compressive flow behavior was also studied for the FSW of Al 2024-T3 and Al 7075-T735 ${ }^{15}$. No information on other welding parameters or the orientations of the alloys has been given.

The two sides of the resulting weld are sometimes asymmetrical, as the result of the tool rotating around itself in a singular direction, creating an advancing side as shown in Figure 2.1 where direction of tool rotation is the same as that of welding, as well as a retreating side where. The differences between the two sides may have different structural properties as a consequence ${ }^{8}$.

As the plunge depth results in longitudinal pressure applied by the tool, causes frictional heat on the surface, affecting the weld quality. With extra pressure possibly leading to overheating or 
extensively damaging the microstructure and low pressure being insufficient for enough plasticity to occur leading to a weakened weld.

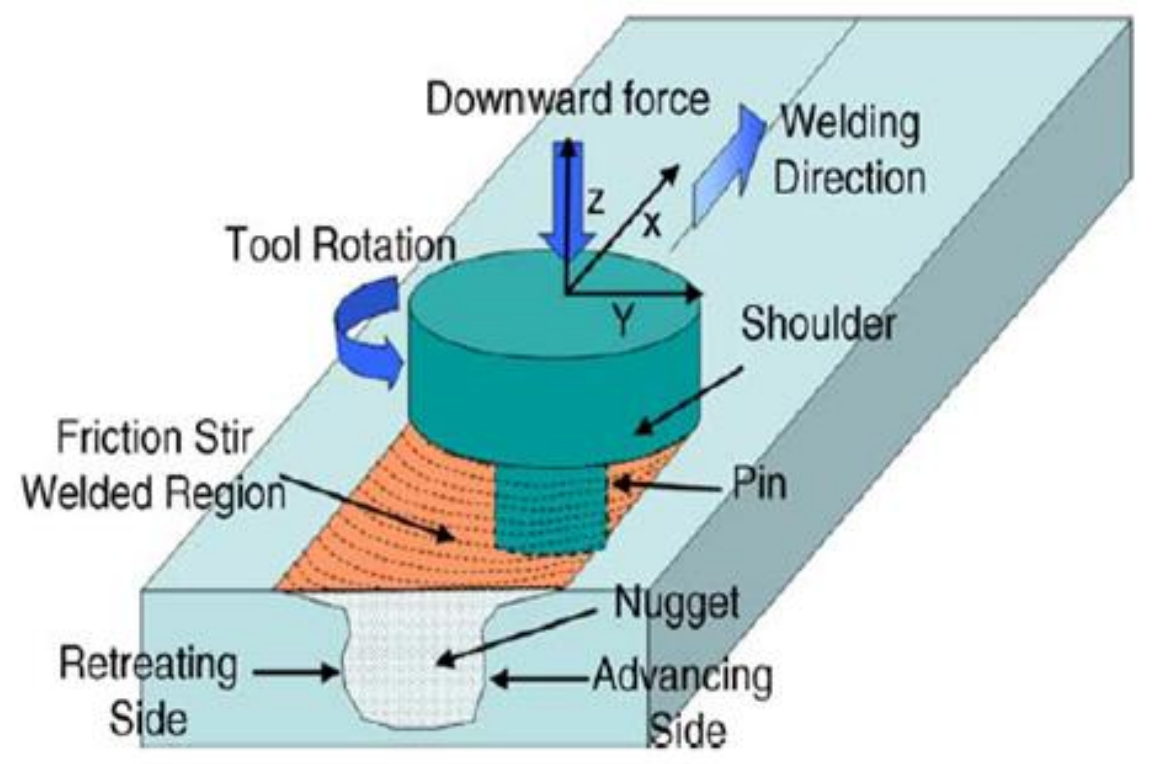

Figure 2.1 Friction Stir Welding Process

Tool rotational speed, travel speed of the tool (welding speed), plunge force, plunge depth, and tool design, are the controlling parameters of the friction stir welding process. These parameters affect the evolved mechanical properties and process-induced damage in the course of the process. The effects of process parameters on the formability of friction stir welded blanks are yet to be determined.

The tool design affects the heat generation, the power required to weld, plastic flow and how uniform the welded joint is. There are two tool surfaces that are required to perform the heating and joining processes. The majority of the heat generated occurs in the shoulder surface if thin 
plates are being dealt with, otherwise however it is the probe surface where the most of the heat is generated. The used tool in the experimental investigation was provided by Boeing Co.

Ductility is an important characteristic in the final product, however, not much research has been conducted on the ductility of friction stir welds. These limitations are addressed in the proposed work using experimental modeling to include all control and uncontrolled (noise) parameters of the FSW process. The results will lead to process conditions that help in identifying process windows for reaching specific properties suitable for the forming stage of HM. Most recently, El-Gizawy et $\mathrm{al}^{3}$ developed a combined numerical and experimental approach for controlling process-induced properties in FSW processes. The numerical component in their approach uses a non-linear finite element method to describe thermal and deformation changes along the joint in FSW. The results obtained on Al 2024-T3 sheets, offer insights into the effects of the major process parameters in processing Al 2024-T3. They help in establishing successful FSW joints that satisfy further processing requirements for Al 2024-T3 sheet service conditions. However, El-Gizawy's results were limited to cases where only similar metals of Al 2024-T3 sheets are considered. In the present work, El-Gizawy's approach ${ }^{3}$ will be extended to cases where dissimilar metals will be investigated. Furthermore, formability of the friction stir welded structure by stretch forming will be evaluated for net-shape production of monolithic structures.

\subsection{STRETCH FORMING}

Sheet metal forming is one of the fundamental processes of metalworking. It is utilized by the transportation industry to meet strength and durability needed for their products. The process is costly and labor intensive, requiring the mechanical joining of forged or casted components. 
Stretch forming is a forming process wherein a sheet of metal is stretched and simultaneously bent over to form a large contoured part. A diagram of sketch forming process is shown in Figure 2.2.

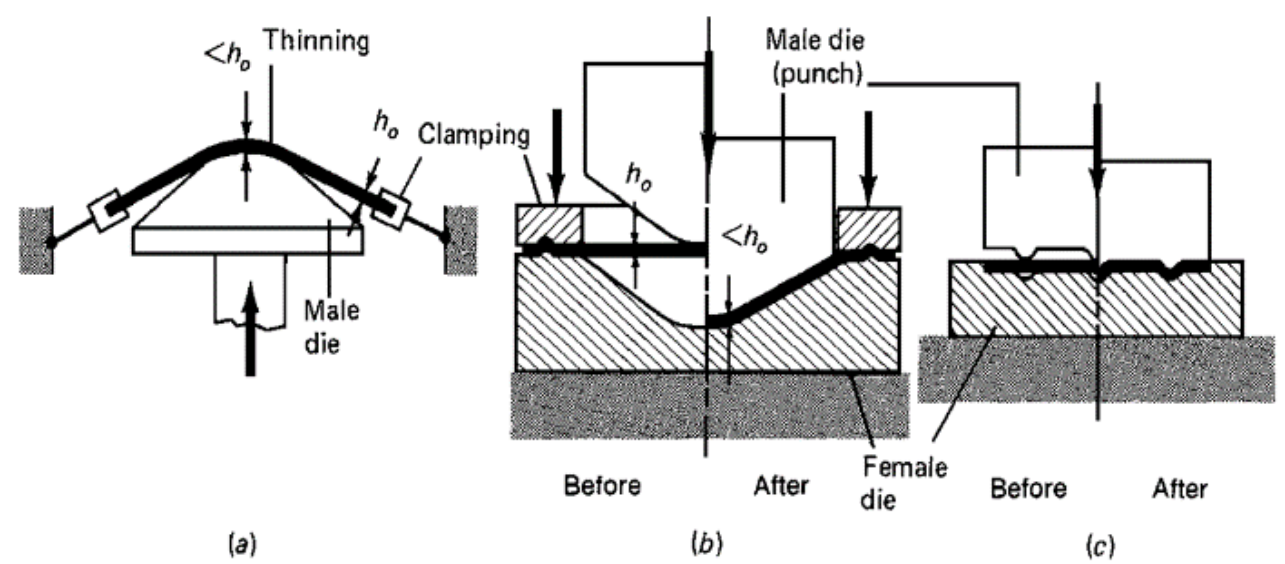

Figure 2.2 Stretch forming processes (a) stretch forming, (b) stretch drawing, and (c) embossing ${ }^{24}$

\subsection{Formability of Welded Preforms}

The orientation of the weld line drastically affects the material flow and formability ${ }^{25}$. Due to the differences in the sheet thickness and property between blanks of joints with dissimilar materials, the welded preform may not deform uniformly during further forming operations. Chan et $\mathrm{al}^{25}$ evaluated formability based on three measures: failure mode, forming limit diagram, and minimum major strain. Their results reveal that the larger gage mismatch of a welded preform, the lower the formability of welded structure. 


\section{CHAPTER 3: EXPERIMENTAL INVESTIGATIONS}

Experimental investigation of the presented HM technology for production of monolithic aerospace structures was systematically planned and conducted. The objectives here is to build a knowledge base of the HM process for high strength aluminum alloys used in aerospace industry.

\subsection{Materials}

Boeing Co. in the United States provided the investigated materials in the present study. They include Al-Zn alloy (7075-T6) and Al-Cu alloy (2024-T3). The combination of lightweight and high strength makes the Al 7075-T6 suitable for structural aircraft parts, while Al 2024-T3 has better formability and corrosion resistance than A1 7075-T6 alloy Chemical Compostion of the alloys is shown in table 3.1 and table 3.2.

Table 3.1 Major Chemical Composition \% of Al 7075-T6

\begin{tabular}{|l|l|l|l|l|l|l|l|l|}
\hline $\mathrm{Al}$ & $\mathrm{Cu}$ & $\mathrm{Mg}$ & $\mathrm{Zn}$ & $\mathrm{Cr}$ & $\mathrm{Mn}$ & $\mathrm{SI}$ & $\mathrm{Fe}$ & $\mathrm{Ti}$ \\
\hline Bal. & $1.2-2.0$ & $2.1-2.9$ & $5.1-6.1$ & $\begin{array}{l}0.18- \\
0.28\end{array}$ & 0.3 & 0.4 & 0.5 & 0.2 \\
\hline
\end{tabular}

Table 3.2 Major Chemical Composition \% of Al 2024-T3

\begin{tabular}{|l|l|l|l|l|l|l|l|l|}
\hline $\mathrm{Al}$ & $\mathrm{Cu}$ & $\mathrm{Mg}$ & $\mathrm{Zn}$ & $\mathrm{Gr}$ & $\mathrm{Mn}$ & $\mathrm{Si}$ & $\mathrm{Fe}$ & $\mathrm{Ti}$ \\
\hline Bal. & $3.8-4.8$ & $1.2-1.8$ & 0.25 & 0.1 & $0.3-0.9$ & 0.5 & 0.5 & 0.15 \\
\hline
\end{tabular}




\subsection{The Material properties}

Properties of Al 7075-T6 and Al 2024-T3 were evaluated experimentally prior to processing them. The ASTM standard ${ }^{26}$ tensile test specimens used were machined from a $2 \mathrm{~mm}$ thick sheet. They were designed to measure the stress and strain with oneinch gage length, the dimensions are shown below in figure 3.1

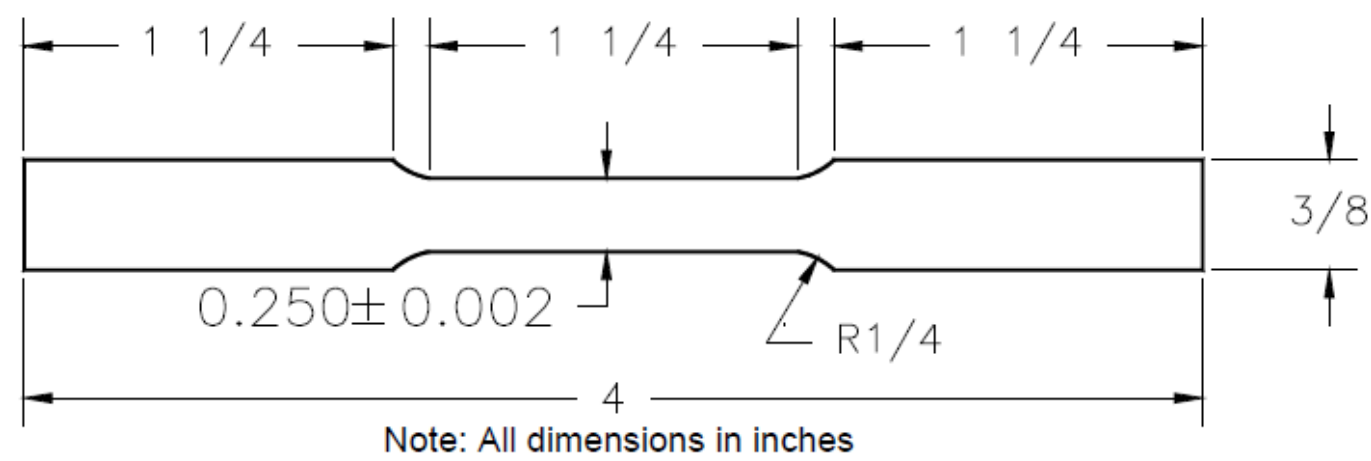

Figure 3.1 ASTM Standard tensile test specimen

Uniaxial experiments were done using an MTS servo hydraulic universal testing machine. It was controlled by a 45.20 MicroConsol and a 41.9 MicroProfiler, used to program the strain rate. A 1-inch extensometer was attached on the middle section of the specimen to have the strain measured, the specimen meanwhile was being clamped between the upper and lower grips. The MicroConsole was recording data about load, displacement and strain in real time by being connected to the Data Acquisition System (DAQ), with process software LabView. The test results for the properties of both materials is shown in Table 3.3. 
Table 3.3 Comparison of properties of Al 7075-T6 and 2024-T3

\begin{tabular}{|l|l|l|}
\hline Property & 7075-T6 & 2024-T3 \\
\hline $\begin{array}{l}\text { Young's Modulus } \\
(\mathrm{GPa})\end{array}$ & 71.7 & 73.1 \\
\hline Poisson's Ratio & 0.33 & 0.33 \\
\hline Density $\left(\mathrm{kg} / \mathrm{m}^{3}\right)$ & 2795.72 & 2780 \\
\hline $\begin{array}{l}\text { Initial Yield Stress } \\
\text { (MPa) }\end{array}$ & 503 & 345 \\
\hline $\begin{array}{l}\text { Ultimate Tensile } \\
\text { Strength (MPa) }\end{array}$ & 578 & 483 \\
\hline Elongation $(\%)$ & 11 & 18 \\
\hline $\mathrm{R}$ Value & 0.68 & 0.65 \\
\hline $\mathrm{K}$ & 756.6 & 430.2 \\
\hline $\mathrm{N}$ & 0.0782 & 0.2288 \\
\hline
\end{tabular}

\subsection{Experimental setup and Procedures}

An adapted milling machine (Figure 3.2) was used to conduct the Friction Stir Welding processes, it has custom fixtures (Figure 3.3) that were designed by a capstone group under the supervision of Dr. El-Gizawy. These fixtures consisted of three main parts; the base plate, parallel bars and the clamps. The base is required to ensure that the aluminum sheet to be welded is sitting on a smooth surface, the base sheet needed to be able to withstand 1500lbs off force exerted by the tool bit; for this A slab of steel with 1.25 " thickness capped with 0.040 " titanium was chosen for the base plate, the titanium was chosen for its low head conductivity to ensure it would not bond with the aluminum and effect the experimental results ${ }^{30}$. To align the aluminum sheet to be welded with the Y-axis motion, pain were placed in the base plate. The base plate was 
keyed into the slots on the mill surface to align it with the table and make sure it is completely square. T-nuts were used to bold the base plate in to prevent it from shifting and ensure stability.

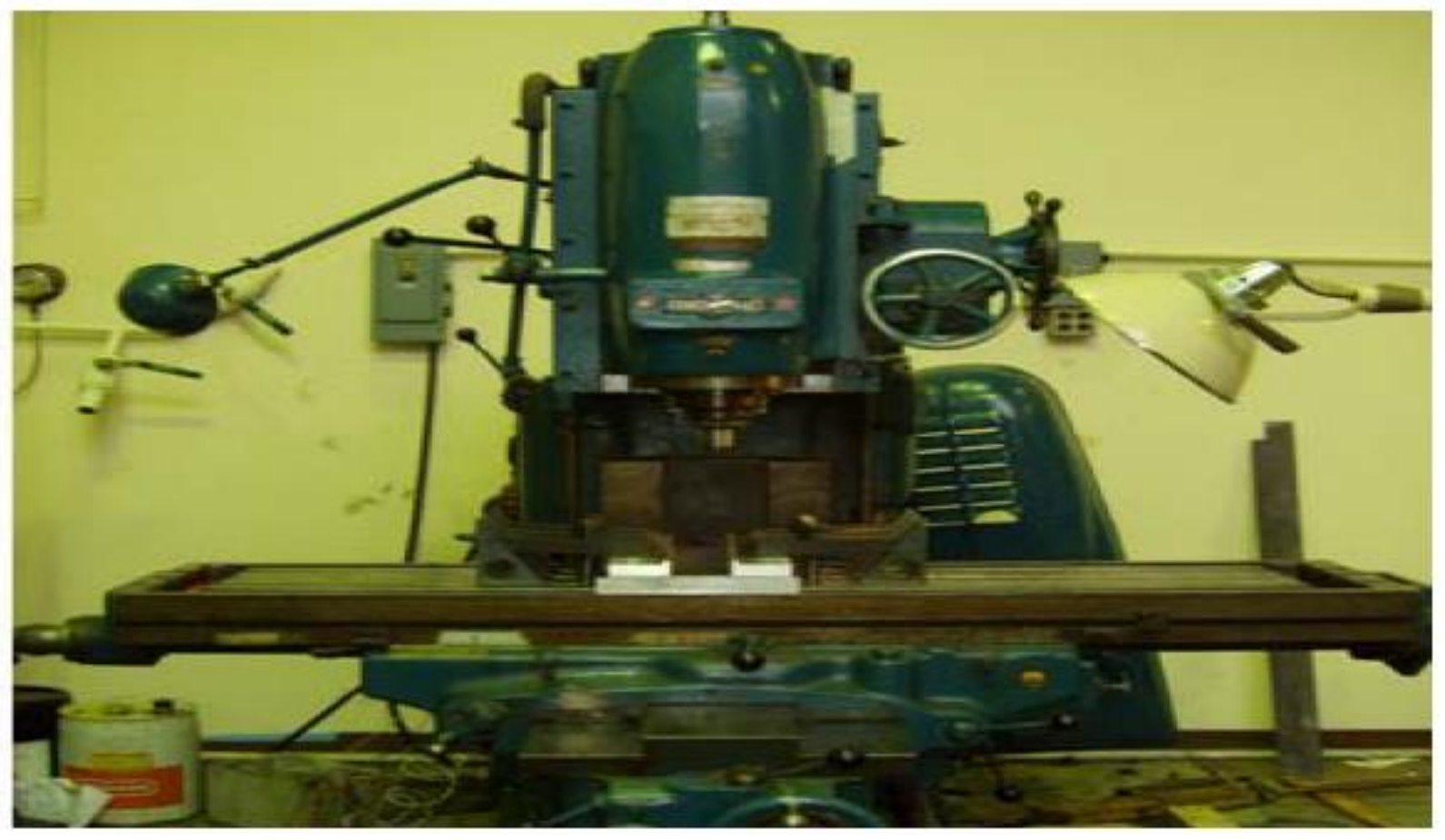

Figure 3.2 Adapted Milling Machine for Friction Stir Welding Process

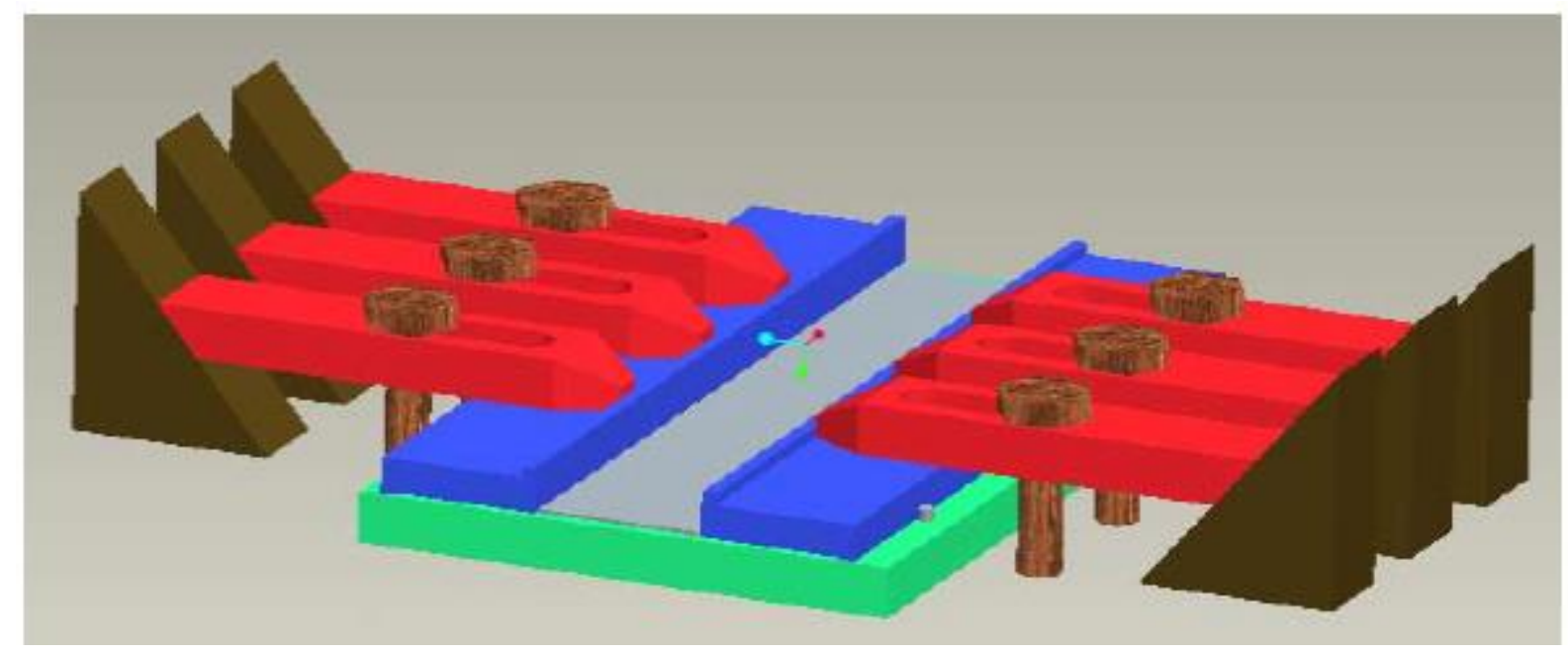

Figure 3.3 Model of Final Design of Friction Stir Welding Fixture 
The parallel bars are used to distribute the load evenly from the clamps along the aluminum sheets and constraining the work pieces from separating in case of butt joint. Because of its lightweight and to keep the bars from marring the aluminum sheets to be welded and to absorb some of the weld heat from along the x-axis, the bars were milled out of aluminum. They covered the entire length of the welding process. A large clamping area was provided with the bars; however, it did not interfere with the tool or the welding procedure. A milled lip of 0.060 " thickness was milled into the bottom of the bars, in order to withstand separation force during the welding process as well as pulling some of the heat from the $\mathrm{x}$-direction and evenly distributing it along the weld area instead of having the heat built up around the clamping system.

Standard issue serrated clamps with step blocks were used. The studs used to hold the clamps to the table are 0.75 " grade $7 \mathrm{~b}$ steel and thread into t-nuts in the tables' channels. All blocks were ensured to be of similar height to ensure equal forces ${ }^{27}$

\subsection{The Tool Bit}

The tool bit (Figure 3.4) is what causes friction in the friction stir welding. Upon contacting the metal, friction is generated and the material is stirred. The tool's shoulder rotates against the substrate generating most heat required for the process, the pin on the tool is plunged into the substrate and helps in stirring the metal in the solid state. The bits showed a good working life; about 30 runs for 12 " a piece working on the aluminum alloys. The tool bits were cleaned promptly after usage with sodium hydroxide to inspect their condition. 


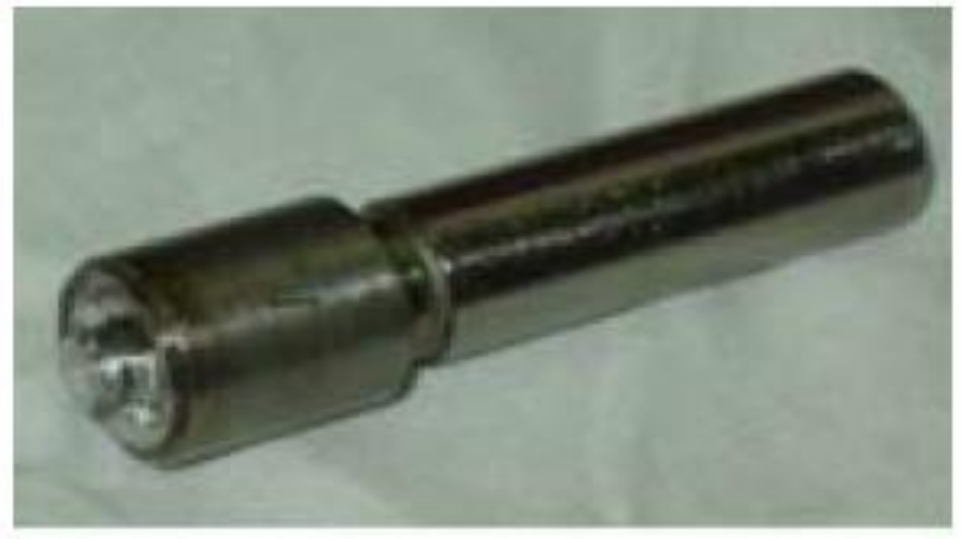

Figure 3.4 Close up of New Tool Bit

\subsection{Friction Stir Welding Devices and Process}

All FSW investigations were conducted on an in-house established FSW rig based on an available vertical milling machine. A special fixture was designed to firmly clamp the sheets. The fixture was also provided with a specially designed support plate.

The two aluminum sheets to be welded were faced up against each other while being clamped using the fixtures discussed beforehand. Translational, Rotational velocity were set in the milling machine. The tool, rotated is thereupon plunged into the work piece. The tool creates heat via friction until the material interface becomes plasticized. Because of the mechanical mixing and adiabatic heat within the material, the stirred material is softened without reaching the melting point. This is one of the major advantages of Friction Stir Welding over conventional welding methods. Once the work area becomes plasticized, the tool traverses along the weld line to bond the materials together. The plasticized material is subsequently deformed around the tool and placed by axial force of the tool shoulder, Material is then consolidated along the weld joint leaving a solid bond between the two pieces ${ }^{29}$. Figures 3.5 displays the initial setup of FSW rig. 


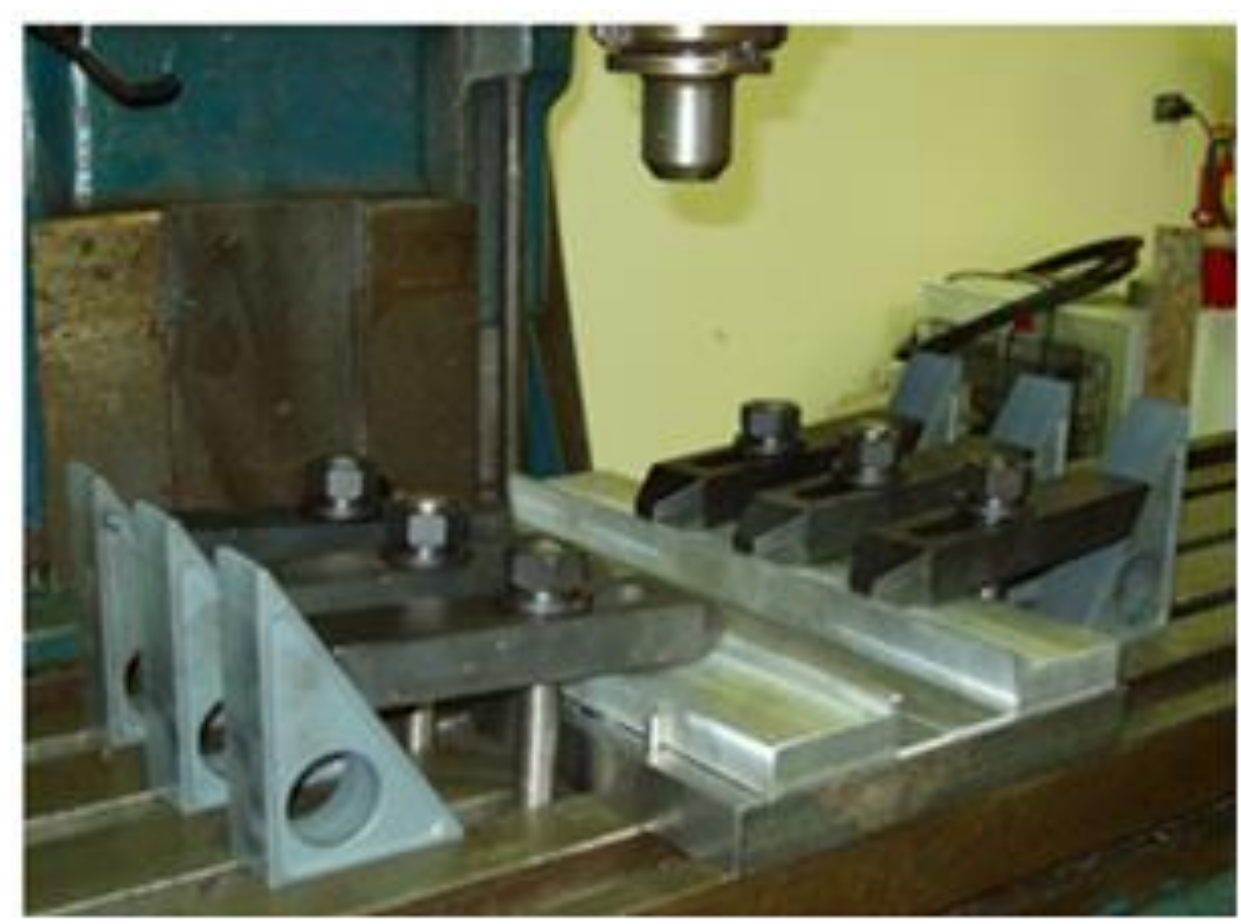

Figure 3.5 FSW rig with the welded sheet holding fixture

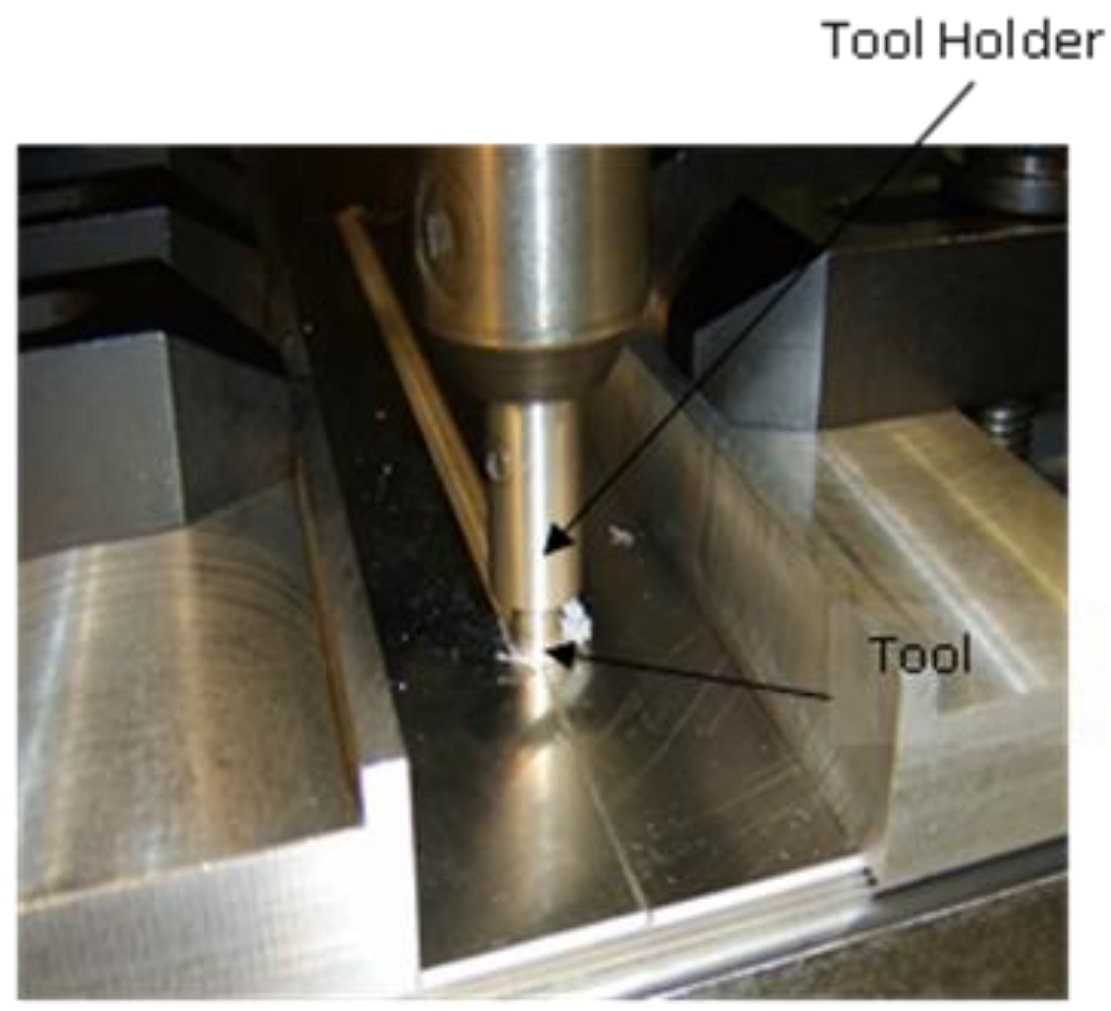

Figure 3.6 FSW rig showing the tool and process pass 


\subsection{Parametric Evaluation of Friction Stir Welding Process}

Parametric investigation using the Taguchi Method was used as this study's Design of Experiment approach to study the effects of the control process parameters on the important quality characteristics of the FSW joints. The Taguchi Method is handy for reducing the required number of tests to have base knowledge on what are the most effective parameters ${ }^{28}$.

Experiments designed to investigate control process parameters were put in order, the control process parameters included the feed rate, and rotational speed on the quality characteristic of the final result was.

\subsubsection{Friction Stir Welding Similar Alloys}

Friction stir welding of similar alloys made out of $\mathrm{Al}$ 2024-T3 was investigated under different combinations of the major FSW parameters, the tool rotational velocity and welding velocity. The experimental $\log$ is displayed in Table 3.4. It should be mentioned that the other FSW parameters were kept constant during this investigation. Table 3.5, shows the values of these fixed parameters.

Table 3.4 Experimental Log for FSW Al 2024-T3 Welds

\begin{tabular}{|l|c|c|}
\hline Sample \# & Rotational Velocity (RPM) & $\begin{array}{c}\text { Welding Velocity } \\
\text { (mm/sec) }\end{array}$ \\
\hline $2024-1$ & 1300 & 0.9 \\
\hline $2024-2$ & 1300 & 1.53 \\
\hline $2024-3$ & 1300 & 2.43 \\
\hline $2024-4$ & 1300 & 3.23 \\
\hline $2024-5$ & 1045 & 2.43 \\
\hline $2024-6$ & 1045 & 1.53 \\
\hline $2024-7$ & 1045 & 3.23 \\
\hline $2024-8$ & 840 & 1.96 \\
\hline $2024-9$ & 840 & 2.43 \\
\hline
\end{tabular}


Table 3.5 Fixed Process Parameters for FSW

\begin{tabular}{|l|l|}
\hline Blank Dimensions & $100 \mathrm{~mm}$ X 300mm X 2mm \\
\hline Type of Weld & Butt Weld \\
\hline Plunge Depth & $2 \mathrm{~mm}$ \\
\hline Plunge Time & 15 seconds \\
\hline Dwell Time & 20 seconds \\
\hline
\end{tabular}

Friction stir welding of similar blanks made out of Al 7075-T6 was conducted to determine the feasible conditions that produce sound welds. Table 3.6 displays the experimental conditions that resulted in successful joints. The same fixed process parameters (Table 3.5) used for welding Al 7075-T6 joints.

Table 3.6 Process parameters for FSW of Al 7075-T6

\begin{tabular}{|l|c|c|}
\hline Sample \# & Rot. Vel. (RPM) & Weld Vel. (mm/sec) \\
\hline $7075-1$ & 1300 & 0.9 \\
\hline $7075-2$ & 1045 & 3.23 \\
\hline $7075-3$ & 840 & 2.43 \\
\hline
\end{tabular}




\subsection{Friction Stir Welding Dissimilar Alloys}

Effects of the major control parameters of FSW (the tool rotational velocity and welding velocity) on the formability of the welded bi-alloy preforms were experimentally evaluated (Table 3.7). The feasible process window for FSW of bi-alloy made out of Al 7075-T6 and Al 2024-T6 (Bi-A) was defined from a few tests conducted prior to establishing the experimental design needed. An orthogonal array "L9" was used to develop process contour maps relating process parameters to strength and formability of the welded bi-alloy blanks.

Table 3.7 L9 Orthogonal Array for Al 7075-T6 \& Al 2024-T6

\begin{tabular}{|r|c|c|}
\hline Sample \# & $\begin{array}{c}\text { Rotational } \\
\text { Velocity } \\
\text { (RPM) }\end{array}$ & $\begin{array}{c}\text { Welding Velocity } \\
\text { (mm/sec) }\end{array}$ \\
\hline Bi-A 1 & 675 & 1.53 \\
\hline Bi-A 2 & 675 & 2.43 \\
\hline Bi-A 3 & 675 & 3.23 \\
\hline Bi-A 4 & 840 & 1.53 \\
\hline Bi-A 5 & 840 & 2.43 \\
\hline Bi-A 6 & 840 & 3.23 \\
\hline Bi-A 7 & 1045 & 1.53 \\
\hline Bi-A 8 & 1045 & 2.43 \\
\hline Bi-A 9 & 1045 & 3.23 \\
\hline & & \\
\hline
\end{tabular}




\subsection{Stretch Forming of FSW Preforms}

Stretch forming is conducted to determine the formability of friction stir welded blanks and the effects of the HM process parameters on quality of the produced monolithic structure.

Experimentally conducted stretch forming to examine the ductility and the formability of friction stir welded blanks and determining the effects of rotation speed, weld velocity on ductility was undertaken. The tool setup for stretch forming process with die, punch blank holders are shown in Figure 3.7. The welded blank (Figure 3.8, 3.9) is tightened by bolts after being placed on the die. Blank holder is applied to prevent the blanks from being drawn in the die when it is punched by the machine, resulting in blanks stretching rather than sheet thinning of material by being drawn.

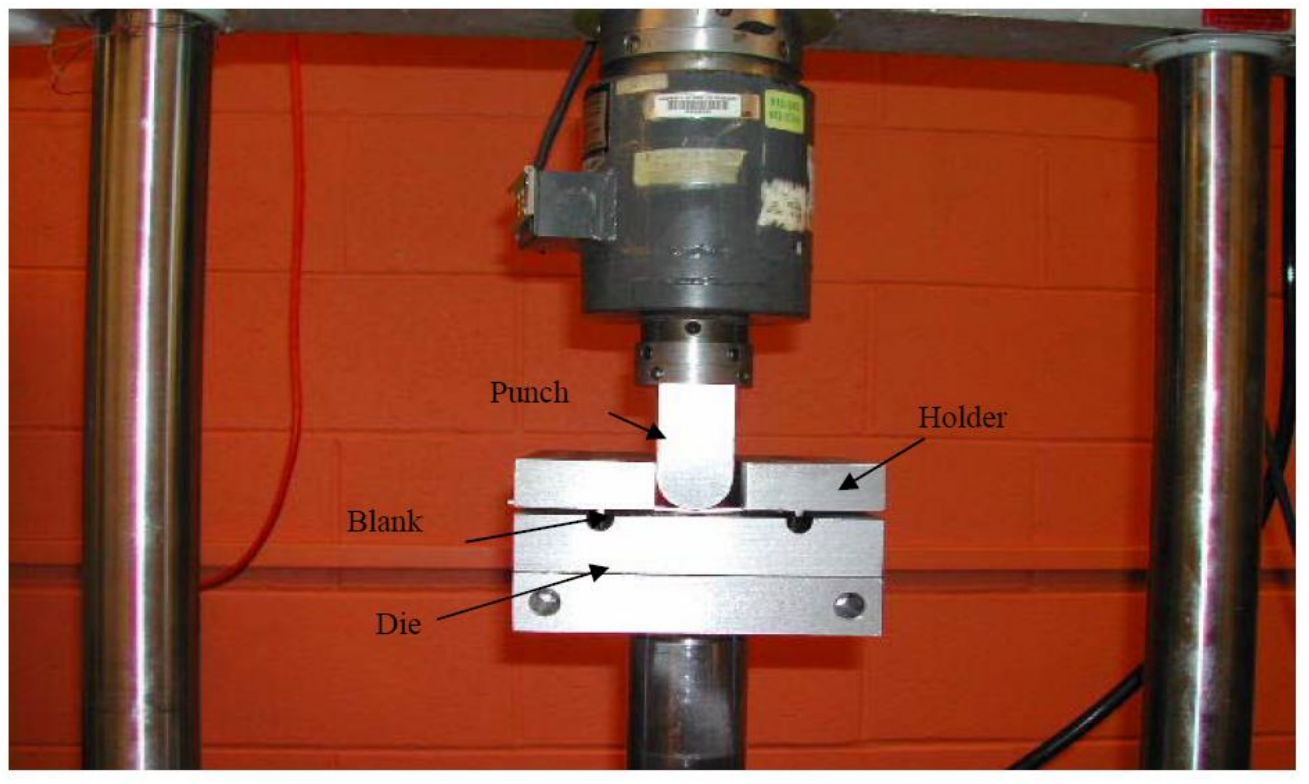

Figure 3.7 MTS Machine with Stretch Forming Fixture 


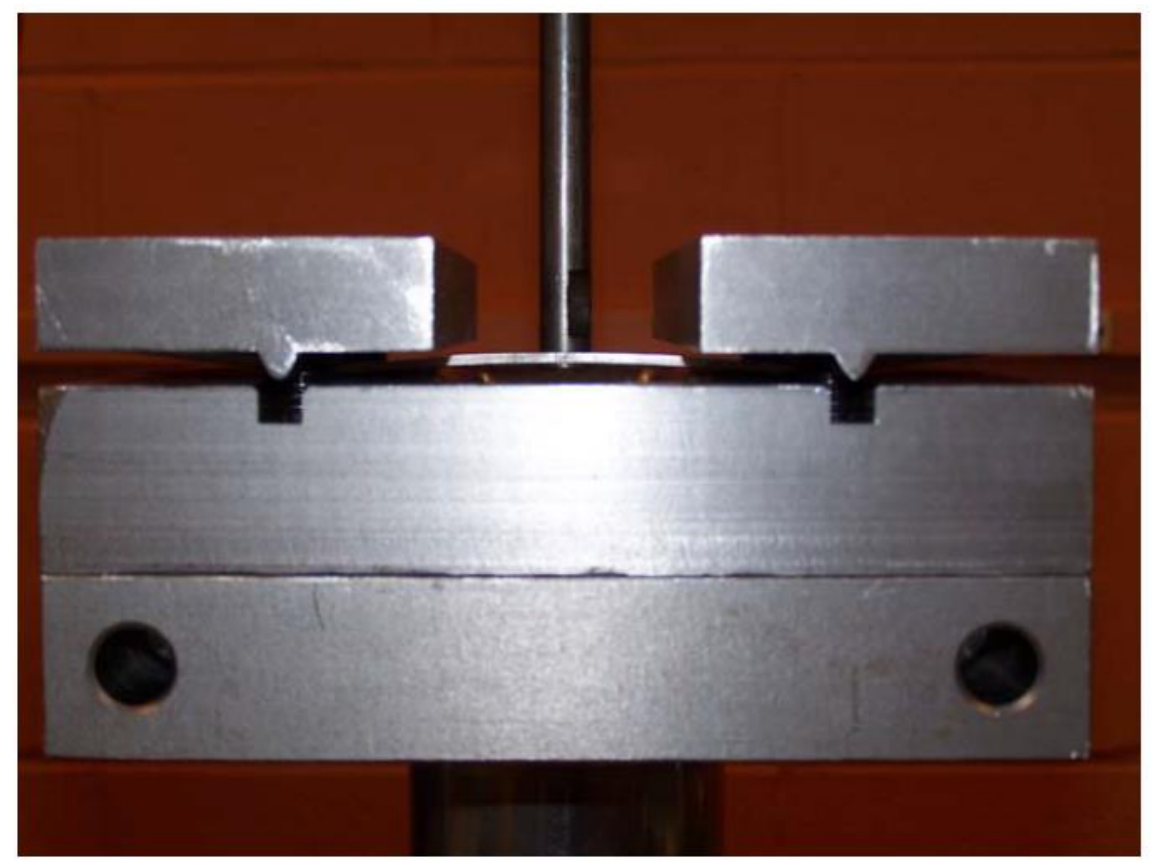

Figure 3.8 Tool Set Up of Stretch Forming Process

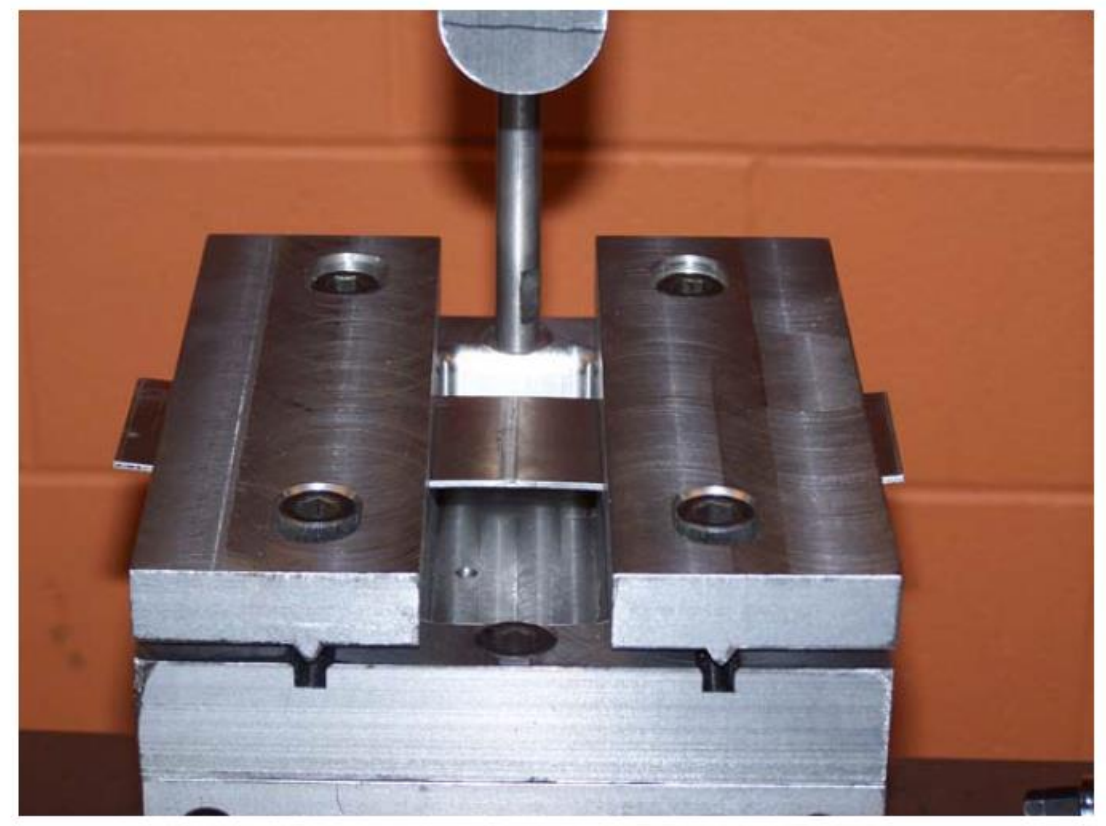

Figure 3.9 Tailor Welded Blank Set up 
The Sheets from friction stir welded blanks of Al 7075-T6 and Al 2024-T3 were stretch formed. The pieces were sheared to $2 \times 8$ " size from $12 \times 8$ " blanks. The prepared work piece was set on the stretch-forming die, with the center of the weld aligned with the center of the die as illustrated in Figure 3.7. The punching parameters were programmed in by the MicroProfiler. The Data Acquisition system was checked beforehand by using LABVIEW, signals from the MircroConsole were processed in real time. The load, displacement and voltage were then plotted on the monitor to help evaluate the process and identify problems.

\subsection{Tensile Testing}

To determine the material properties of the resulting weld, uniaxial experiments were conducted via a MTS servo-hydraulic testing machine. The machine was controlled with the same MicoConsole, MicroProfiler that were used for programming the strain rate. The specimen (Figure 3.10) was clamped between upper and lower grips (Figure 3.11) and an extensometer (Figure 3.12) was attached to the middle section for measuring of the strain.

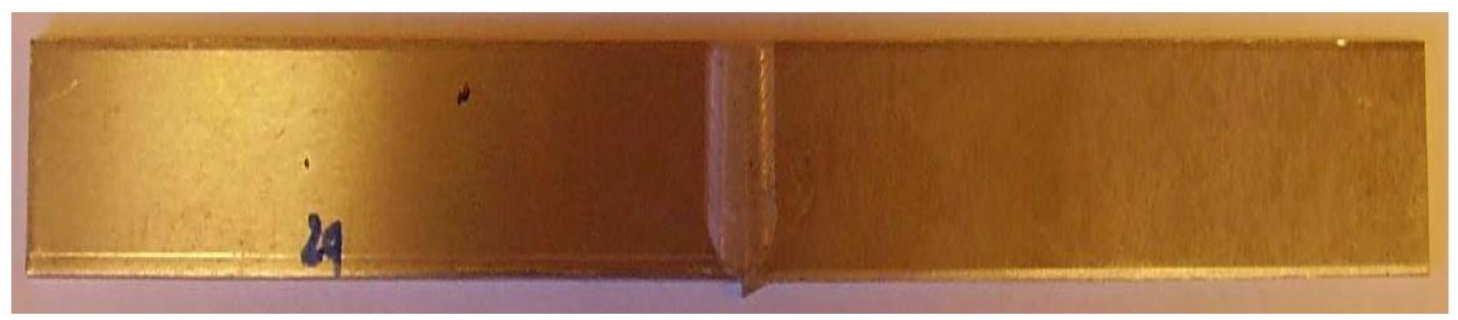

Figure 3.10 Tensile testing specimen 
The samples were initially checked for any imperfections then used, a MicroConsole connected to a Data Acquisition System through with process software LabView were used to record data in real time. The data included load, displacement and strain. The tests were conducted in room temperature. For evaluation the mechanical properties of the welded joints; standard tensile test procedures were followed. The gage dimensions of the specimens were $25.4 \mathrm{~mm}(1$ ") long and $19 \mathrm{~mm}(3 / 4$ ") wide and with the weld zone running across the gage length. The test speed was kept constant at $1 \mathrm{~cm} / \mathrm{min}$ for the duration of the test. All results are an average of three tested samples.

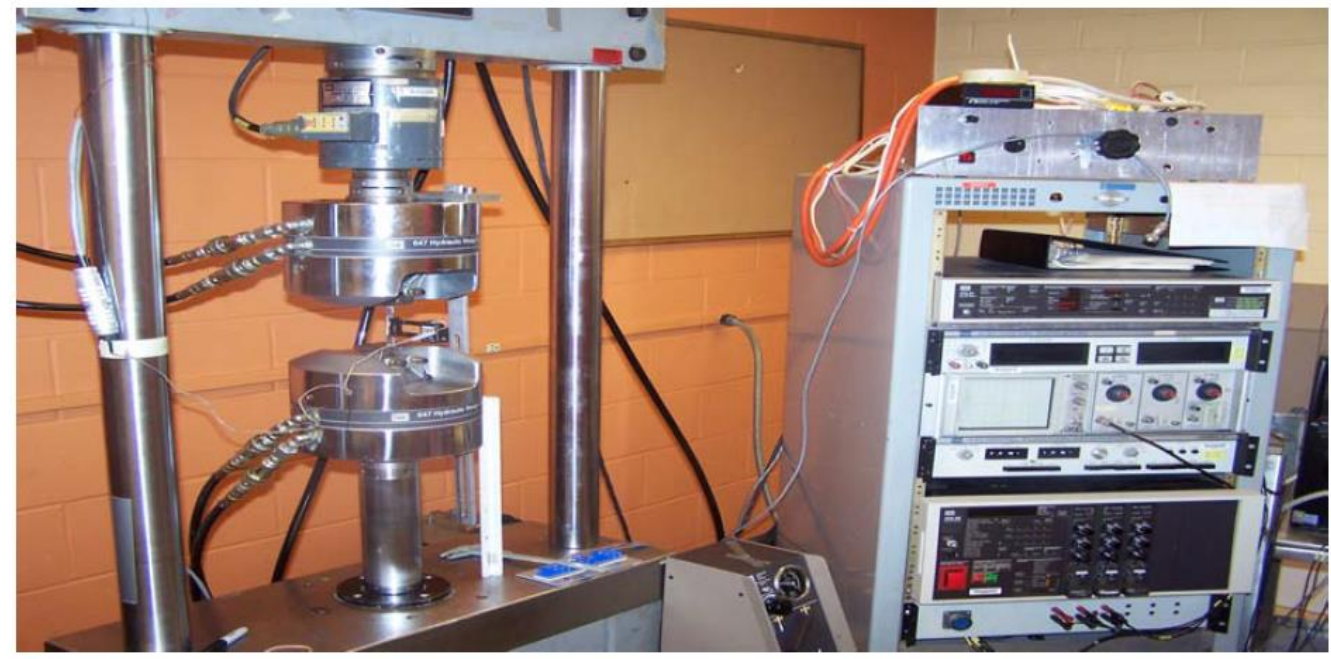

Figure 3.11 Hydraulic Linear Displacement Machine with Extensometer on the clamped sample 


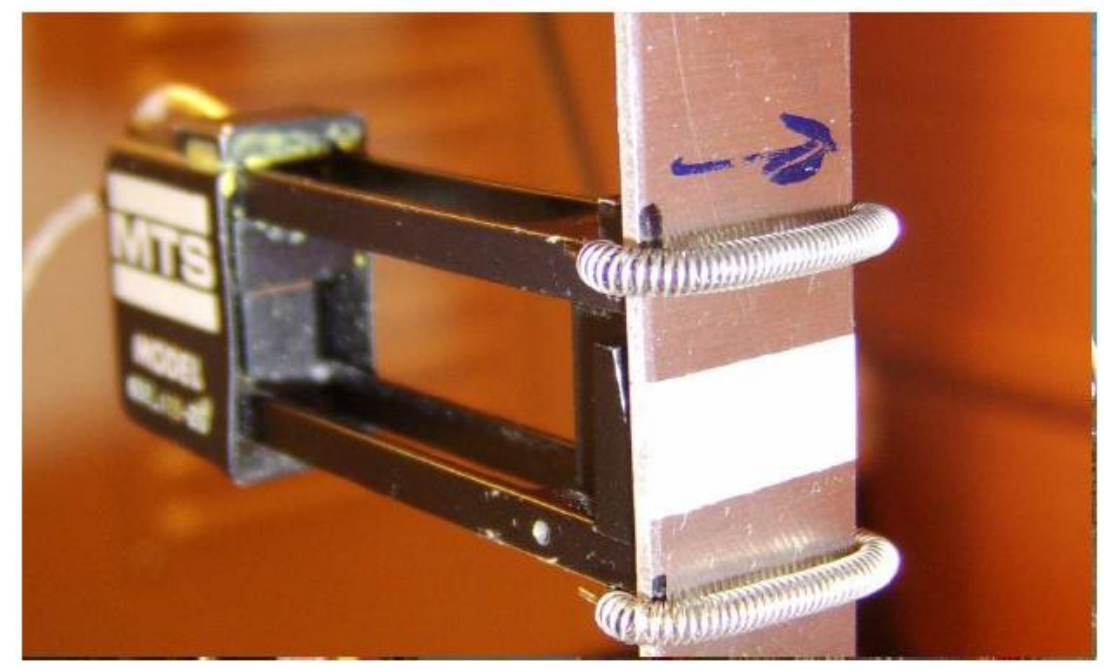

Figure 3.12 Close up of Extensometer 


\section{CHAPTER 4: RESULTS AND DISCUSSIONS}

\subsection{Process-induced Properties of FSW Similar Alloys}

This current study has three stages. In the first stage, a systematic study with differing parameters of friction stir welding for similar alloy Al 2024-T3, followed by a study of bi-alloy material (Al-2024-T3 and AL 7075-T6) followed by stretch forming.

A universal testing machine was used to determine the mechanical properties of the weld and to investigate the effect of the process parameters mechanical properties of the weld to determine the effect of the process parameters. Tensile test was conducted with the specimens cut out of welded blank from every case study using the MTS machine and data acquisition system operated using LabVIEW. Mechanical properties like Yield Strength and Ultimate Tensile Strength of Similarar are summarized in Table 4.1. 
Table 4.1 Mechanical Properties of Al 2024-T3 Welds

\begin{tabular}{|l|l|l|l|l|l|l|}
\hline $\begin{array}{l}\text { Sample } \\
\#\end{array}$ & $\begin{array}{l}\text { Rot. } \\
\text { Vel. } \\
(\mathrm{rpm})\end{array}$ & $\begin{array}{l}\text { Weld } \\
\text { Vel. } \\
(\mathrm{mm} / \mathrm{s})\end{array}$ & $\begin{array}{l}\% \\
\text { Elong }\end{array}$ & $\begin{array}{l}\% \\
\text { Red. } \\
\text { In } \\
\text { Area }\end{array}$ & $\begin{array}{l}\text { YS } \\
(\mathrm{MPa})\end{array}$ & $\begin{array}{l}\text { UTS } \\
(\mathrm{MPa})\end{array}$ \\
\hline $2024-1$ & 1300 & 0.90 & 12.37 & 14.58 & 211.52 & 324.28 \\
\hline $2024-2$ & 1300 & 1.54 & 16 & 12.13 & 319.36 & 437.66 \\
\hline $2024-3$ & 1300 & 2.43 & 10.67 & 5.95 & 313.17 & 407.01 \\
\hline $2024-4$ & 1300 & 3.23 & 6.49 & 9.23 & 301.38 & 429.48 \\
\hline $2024-5$ & 1045 & 2.43 & 18.18 & 17.08 & 309.75 & 406.86 \\
\hline $2024-6$ & 1045 & 1.54 & 11.4 & 7.09 & 330.66 & 445.23 \\
\hline $2024-7$ & 1045 & 3.23 & 8.49 & 8.85 & 314.57 & 424.62 \\
\hline $2024-8$ & 840 & 1.96 & 12.73 & 11.17 & 303.69 & 418.08 \\
\hline $2024-9$ & 840 & 2.43 & 11.18 & 10.03 & 310.56 & 424.73 \\
\hline
\end{tabular}

Data in Table 4.1 represents strength and ductility measures of Al 2024-T3 joints established using different combinations of rotational velocity and welding speed. From the results shown in Table 4.1, conditions in experiment \#5 (rotational velocity of 1045rpm and welding velocity of $2.43 \mathrm{~mm} / \mathrm{sec}$ ) created the weld with the most desirable properties. It has the best combination of strength and ductility (high toughness). The results from Table 4.1 were plotted onto threedimensional surfaces relating the effect of the rotational velocity and welding velocity to the percentage of elongation to failure of the sample. The fitted surface is displayed in Figure 4.1. The contour map for joint ductility, extracted from the surface plot, is shown in Figure 4.2. These figures indicate that rotational velocity in the range of 800 to $1100 \mathrm{rpm}$ and welding velocity of $1.90-2.75 \mathrm{~mm} / \mathrm{s}$ would yield acceptable joint ductility for further processing. 


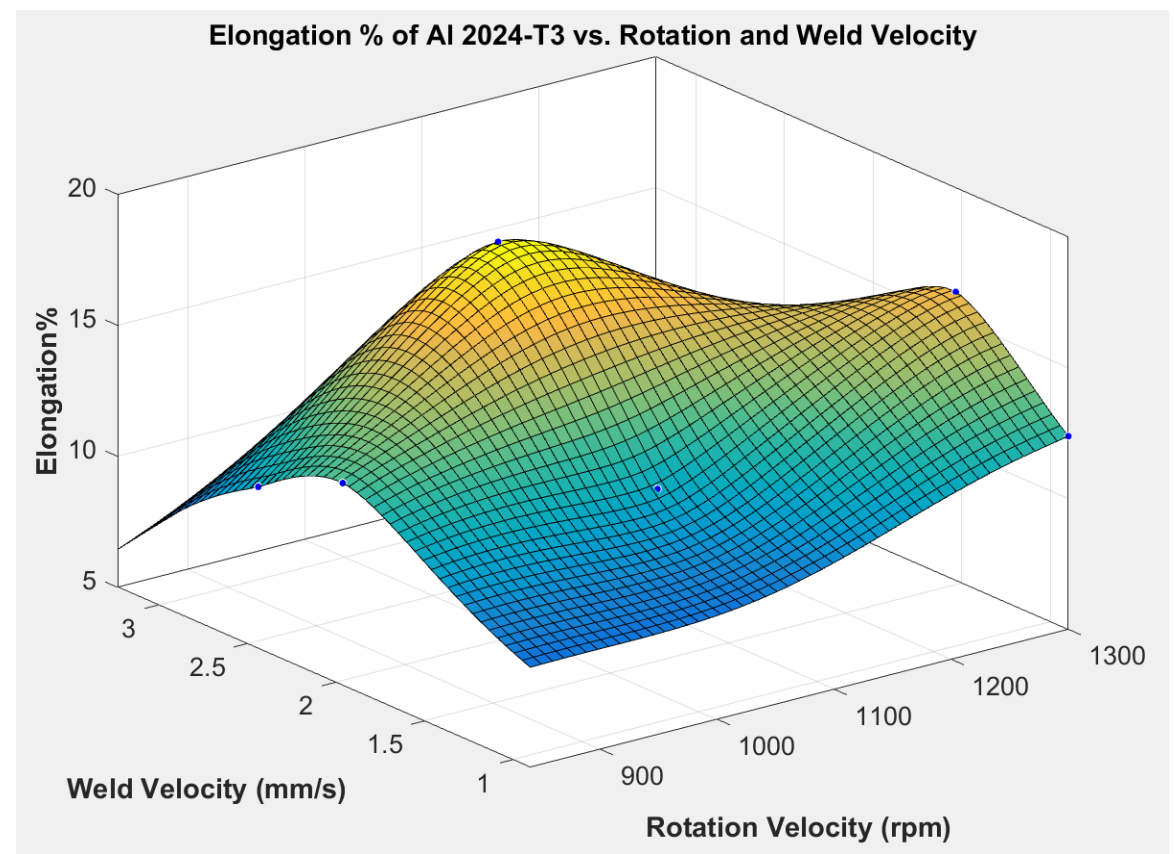

Figure 4.1 Surface plot of the effect of weld and rotation velocity on ductility of FSW Al 2024-T3 Welds.

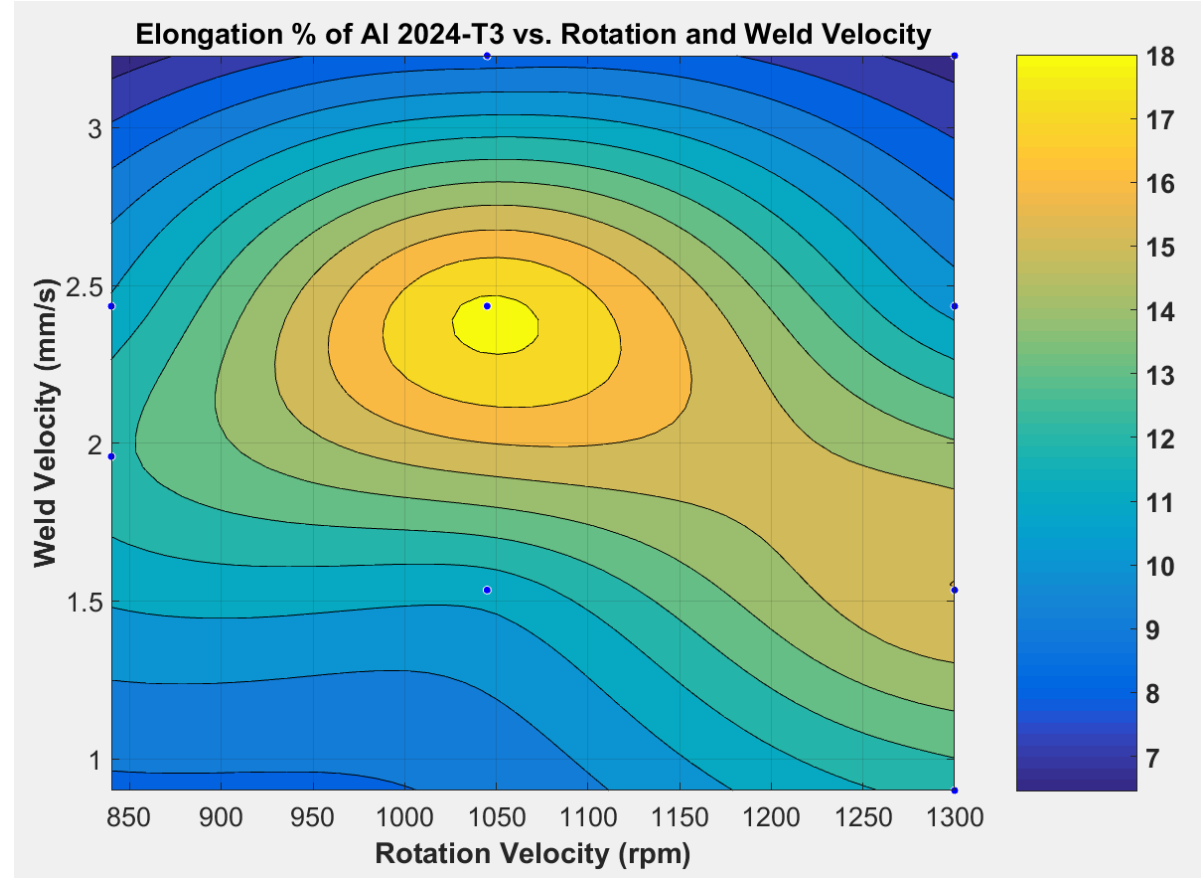

Figure 4.2 Process contour map for ductility index (\% elongation) of FSW Al 2024-T3 joints 


\subsection{Process-induced Properties of FSW Dissimilar Alloys.}

Mechanical properties listed in Table 4.2 show the effect of process parameters on the quality of FSW dissimilar alloys. It can be seen that $\mathrm{Bi}-\mathrm{A} 2$ creates the weld with the highest strength. Bi-A 2 produces a weld that is $18 \%$ stronger than the weakest weld. Insufficient heat is generated with the combination of higher weld velocity and lower rotational velocity (Bi-A 3); this does not provide the ideal condition for the FSW tool to soften and stir the material. However, lower weld velocity and higher rotational velocity of the tool (Bi-A 7) leads to high friction and excessive heat generated between the tool and blanks. Process parameters used in $\mathrm{Bi}-\mathrm{A} 2$ provides the optimal condition to generate heat in order to soften and perfectly stir the material leading to a complete solid weld.

Ductility of the preform generated with conditions listed in experiment Bi-A 2 is above 12\%, which is suitable for further processing with stretch forming. The high joint strength of $416 \mathrm{MPa}$ of weld Bi-A 2 combined with the mentioned high ductility would give the structure excellent toughness needed for aerospace structures. Figure 4.3 displays the response surface of ductility as a function of rotational velocity and welding velocity. The process contour map generated from Figure 4.3 is presented in Figure 4.4. The results indicate that rotational velocity in the range of 1045 to $1300 \mathrm{rpm}$ and welding velocity of 1.5-2. $5 \mathrm{~mm} / \mathrm{s}$ would yield optimum joint ductility with reasonable strength. 
Table 4.2 Mechanical Properties of Al 7075-T6/Al 2024-T3 Welds

\begin{tabular}{|l|c|c|c|c|c|}
\hline Case \# & $\begin{array}{c}\text { Rot. Vel. } \\
(\text { RPM) }\end{array}$ & $\begin{array}{c}\text { Weld Vel. } \\
(\mathbf{m m} / \mathbf{s})\end{array}$ & \% Elong. & YS (MPa) & UTS (MPa) \\
\hline Bi-A 1 & 1300 & 0.90 & 6.8 & 320 & 395 \\
\hline Bi-A 2 & 1300 & 1.54 & 12.3 & 325 & 416 \\
\hline Bi-A 3 & 1300 & 2.43 & 9.9 & 335 & 355 \\
\hline Bi-A 4 & 1300 & 3.23 & 7.2 & 315 & 355 \\
\hline Bi-A 5 & 1045 & 2.43 & 5.9 & 335 & 354 \\
\hline Bi-A 6 & 1045 & 1.54 & 12.5 & 335 & 360 \\
\hline Bi-A 7 & 1045 & 3.23 & 7.9 & 317 & 351 \\
\hline Bi-A 8 & 840 & 1.96 & 8.9 & 335 & 364 \\
\hline Bi-A 9 & 840 & 2.43 & 7.4 & 345 & 355 \\
\hline
\end{tabular}

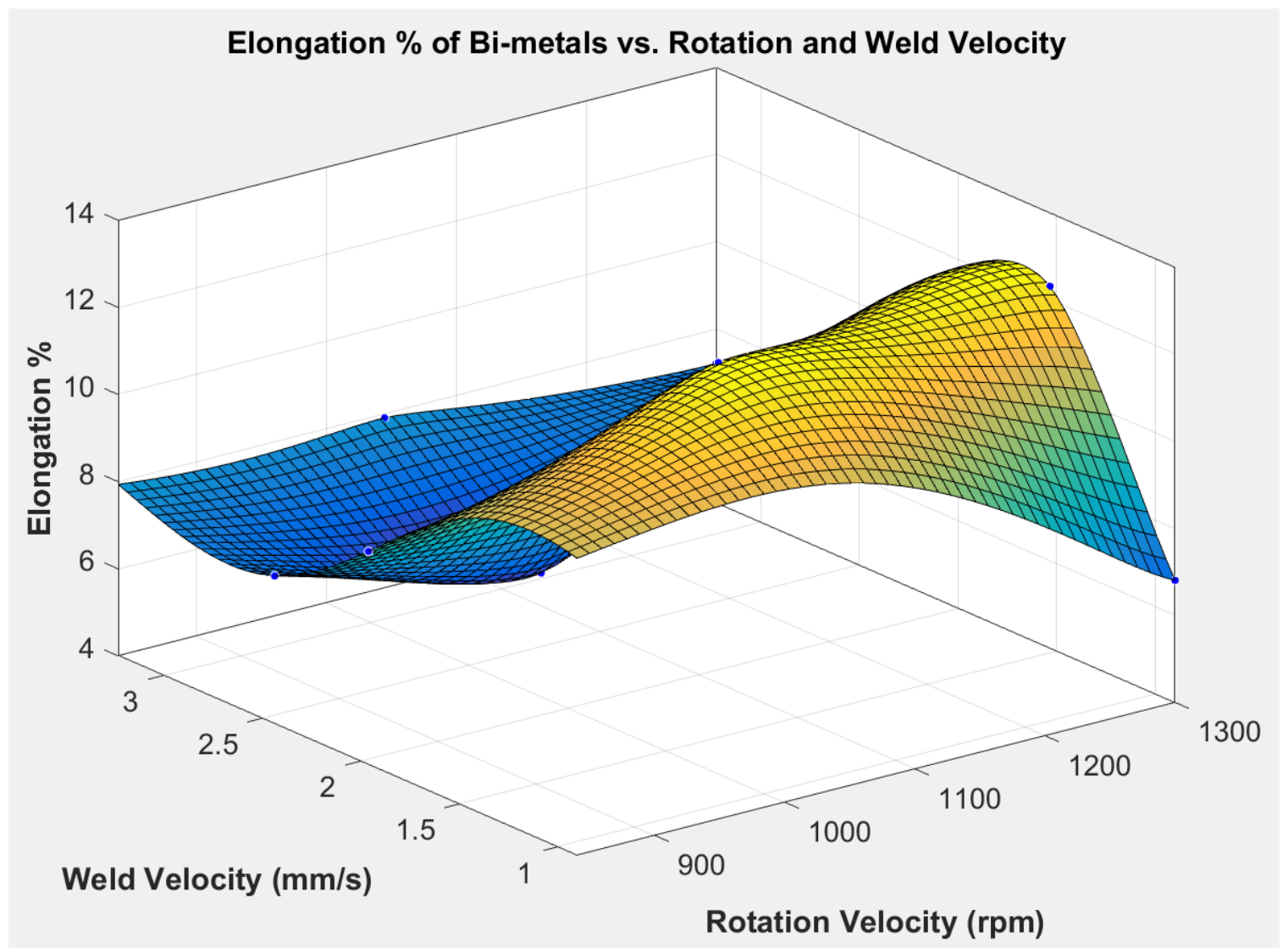

Figure 4.3 Surface plot of the effect of weld and rotation velocity on ductility of Bi-metals Al 2024-T3/Al 7075-T6 welds. 


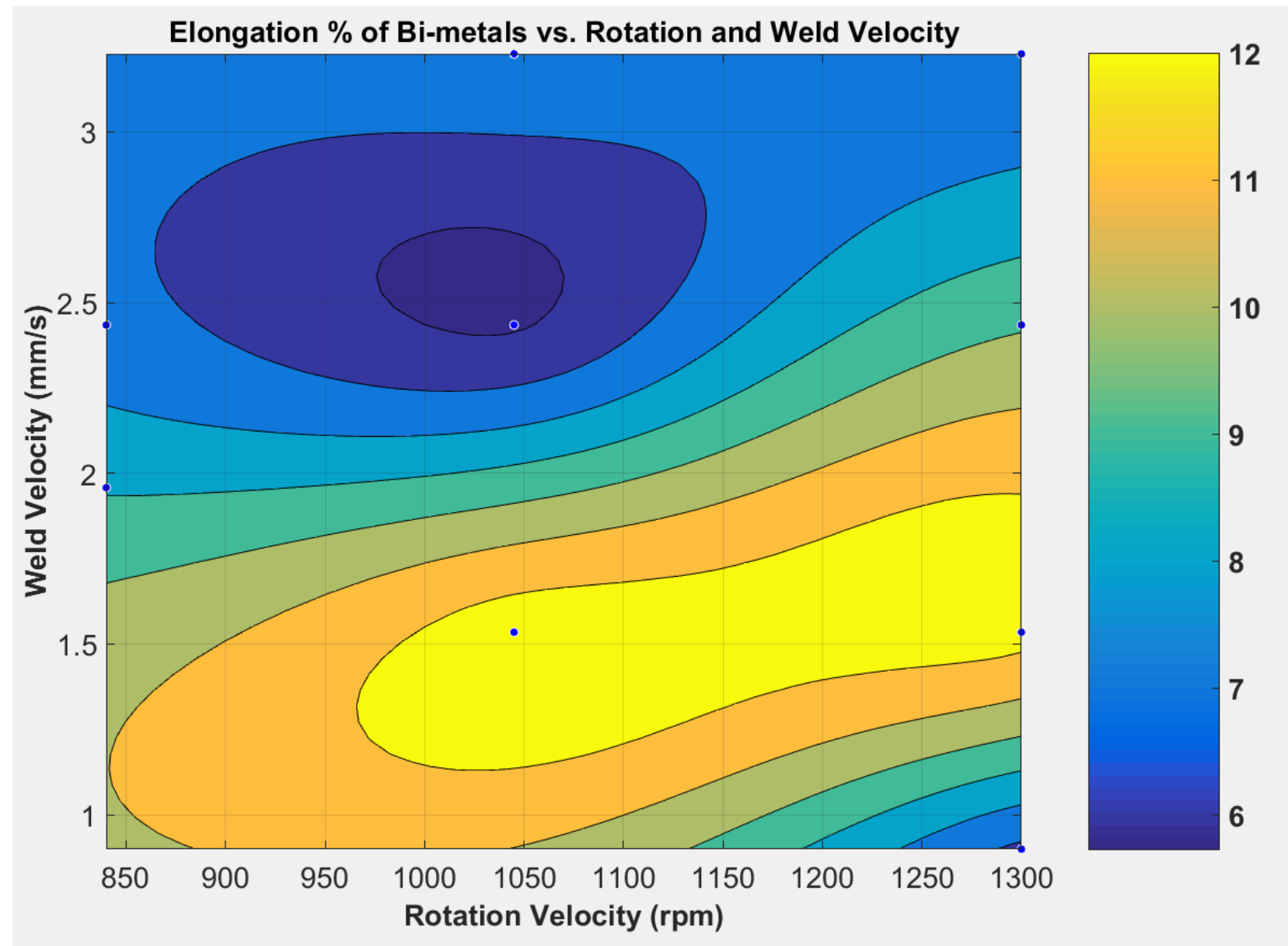

Figure 4.4 Process contour map for ductility index (\% elongation) of Bi-metals Al2024-T3/Al 7075-T6 joints.

From the stress-strain curve shown in Figure 4.5, it can again be shown that Bi-A2 had the highest strength, in Figure 4.6 it is shown to have the optimal qualities of a hybrid, with higher strength than Al 2024-T3 and higher ductility than 7075-T7, showing the success of the process. 


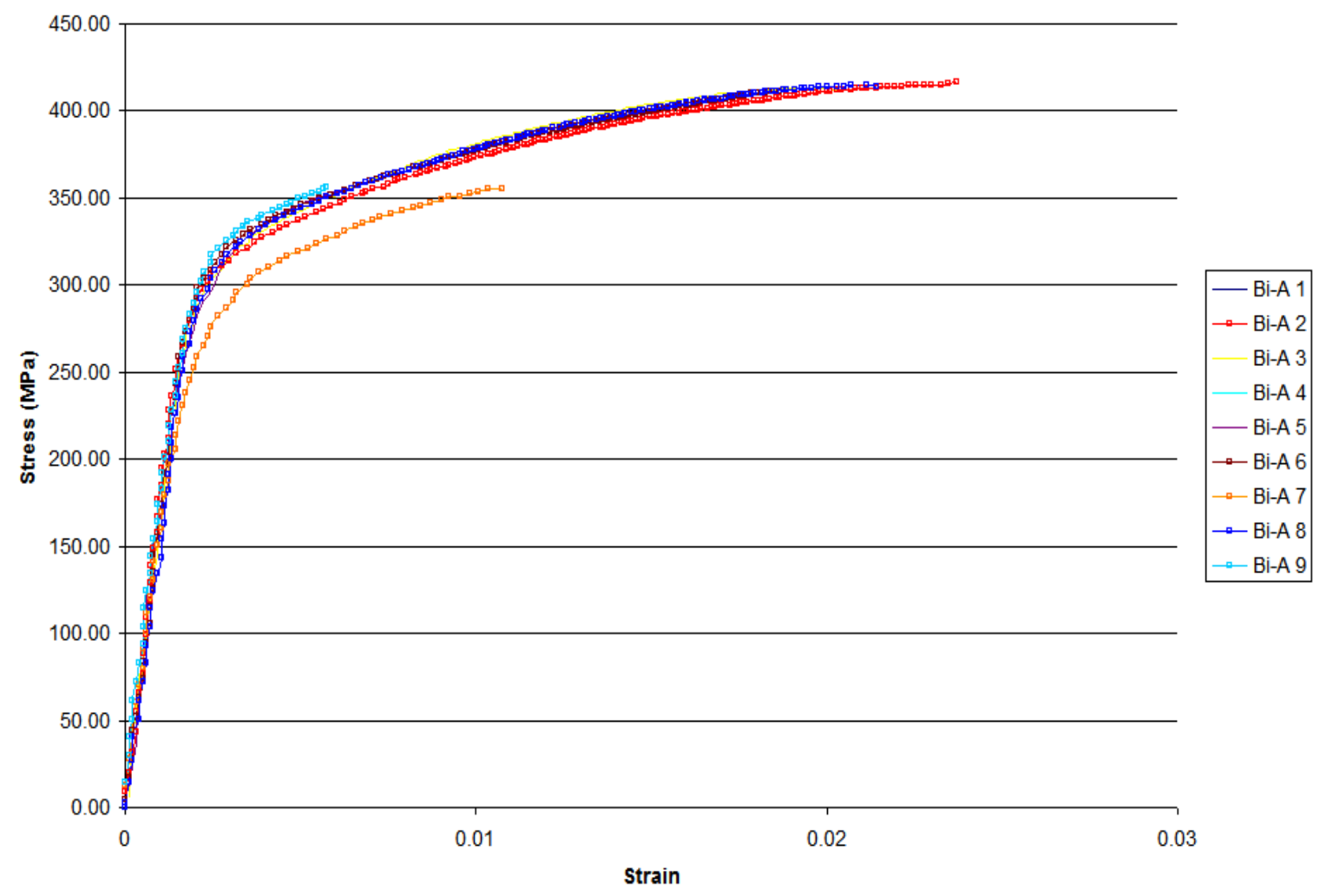

Figure 4.5 Stress-strain of different cases

The elongation presented in Table 4.2 also show that $\mathrm{Bi}-\mathrm{A} 2$ has the second highest elongation of the tested welds, at $9.4 \%$, with Bi-A6 having the highest elongation at $10.2 \%$ with both cases having comparable reduction in area. 
Stress Vs Stress

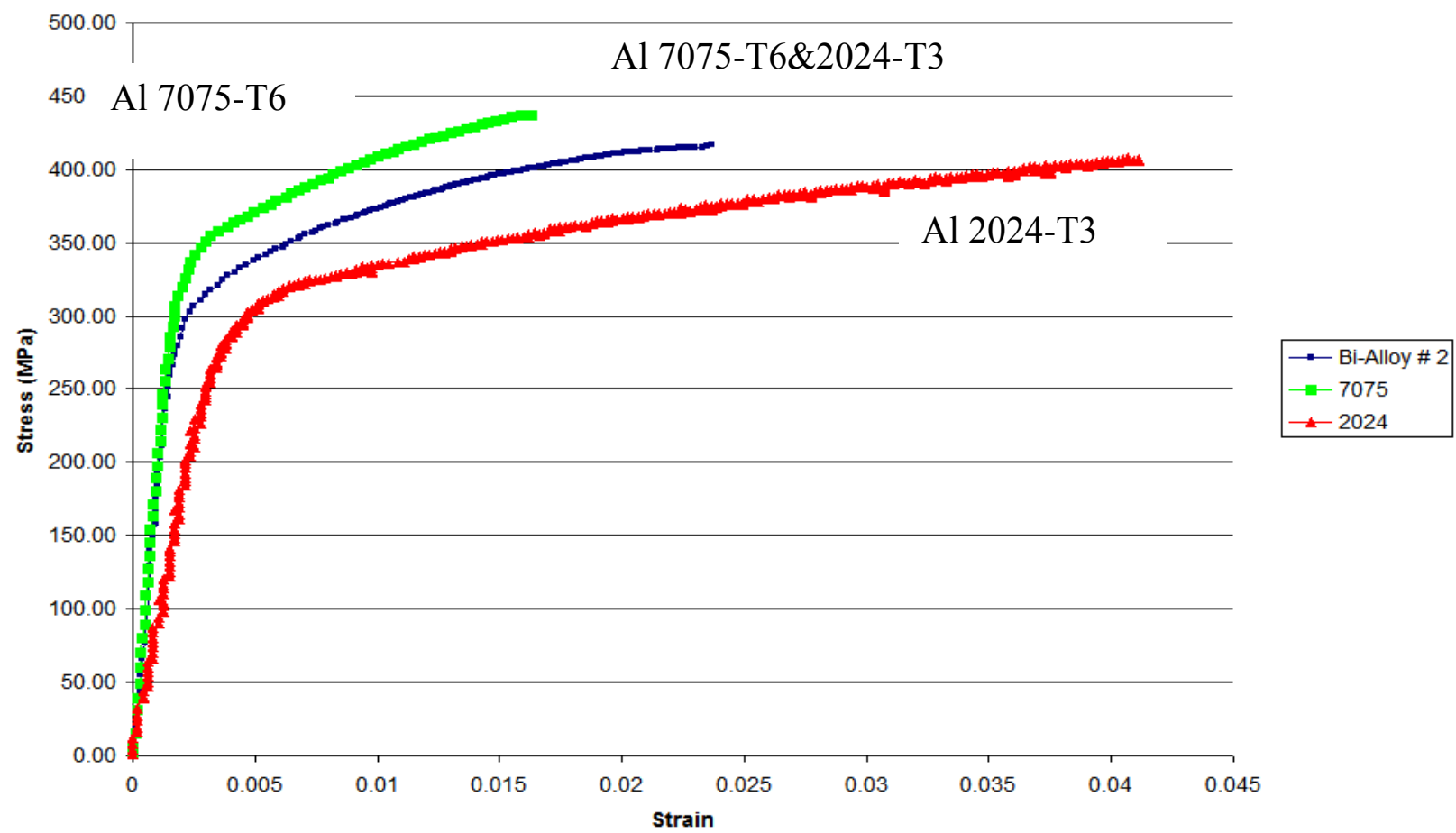

Figure 4.6 Comparison of Stress-Strain curves of 2024, 7075 and Bi-A2 


\subsection{Stretch Forming of FSW Preforms}

Using the MTS machine the stretch forming experiments were carried at fixed parameters on FSW bi-alloy Al 2024-T3/Al 7075-T6 structures with a constant punch velocity of $10 \mathrm{~mm} / \mathrm{min}$. The blanks are firmly clamped using the blank holder. The ' $\mathrm{V}$ ' shaped notch in the blank holder helps to hold the blank into the groove in the die, thus preventing the blank from slipping as the punch moves in to deform the blank. The stretch forming process is continued until failure of the blank. The welded blank after the failure is shown in Figure 4.14. Final stretch blank shown in Figure 4.15.

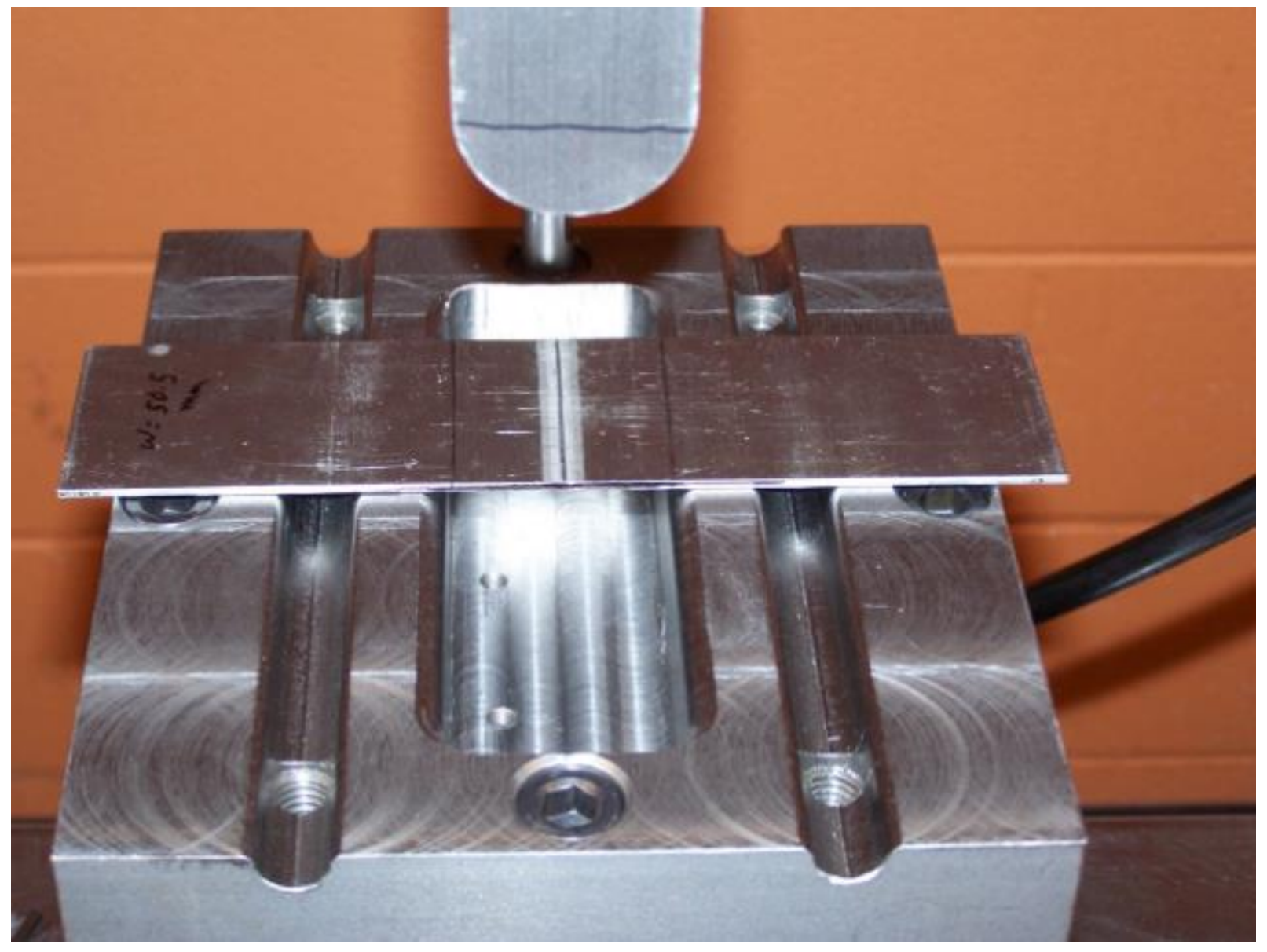

Figure 4.7 Tailored Welded Preform before Forming 


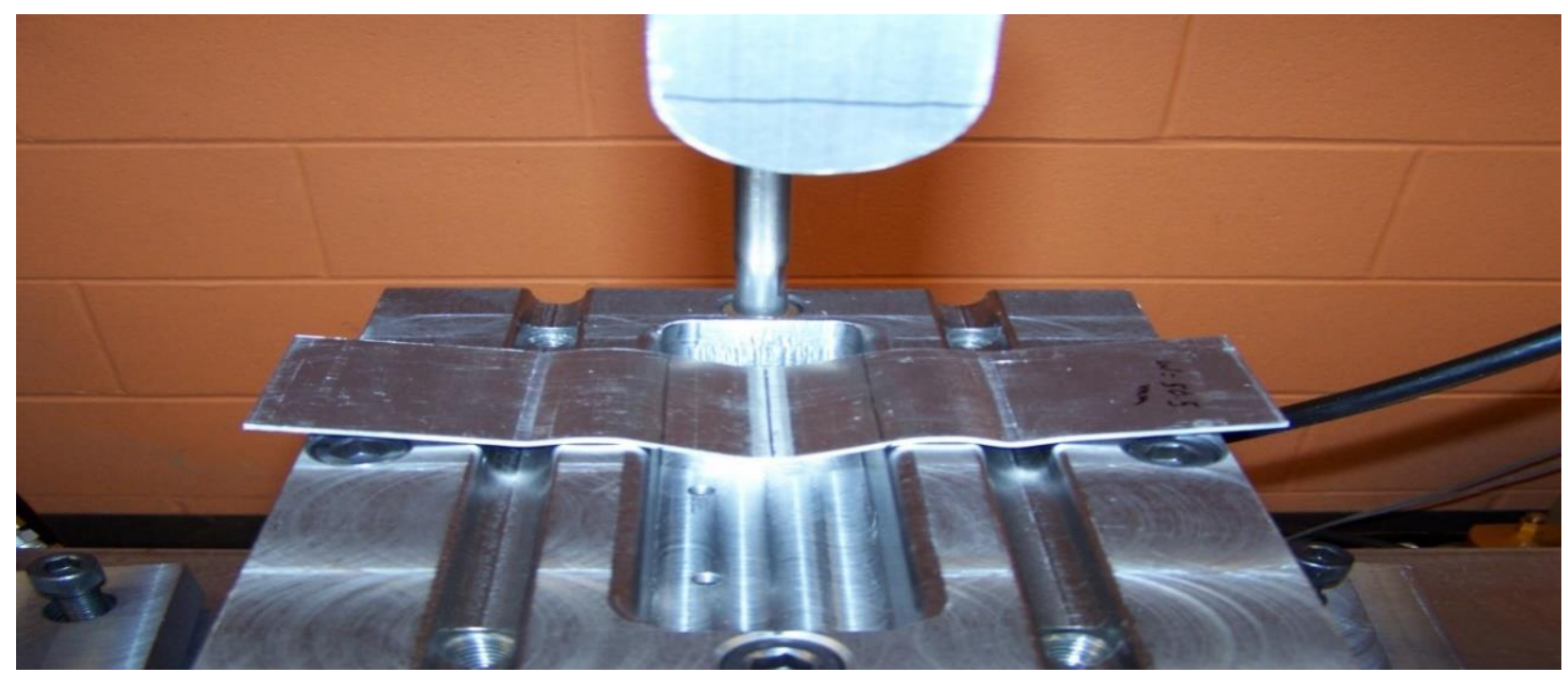

Figure 4.8 Failed Tailored Welded Preform after Stretch Bending

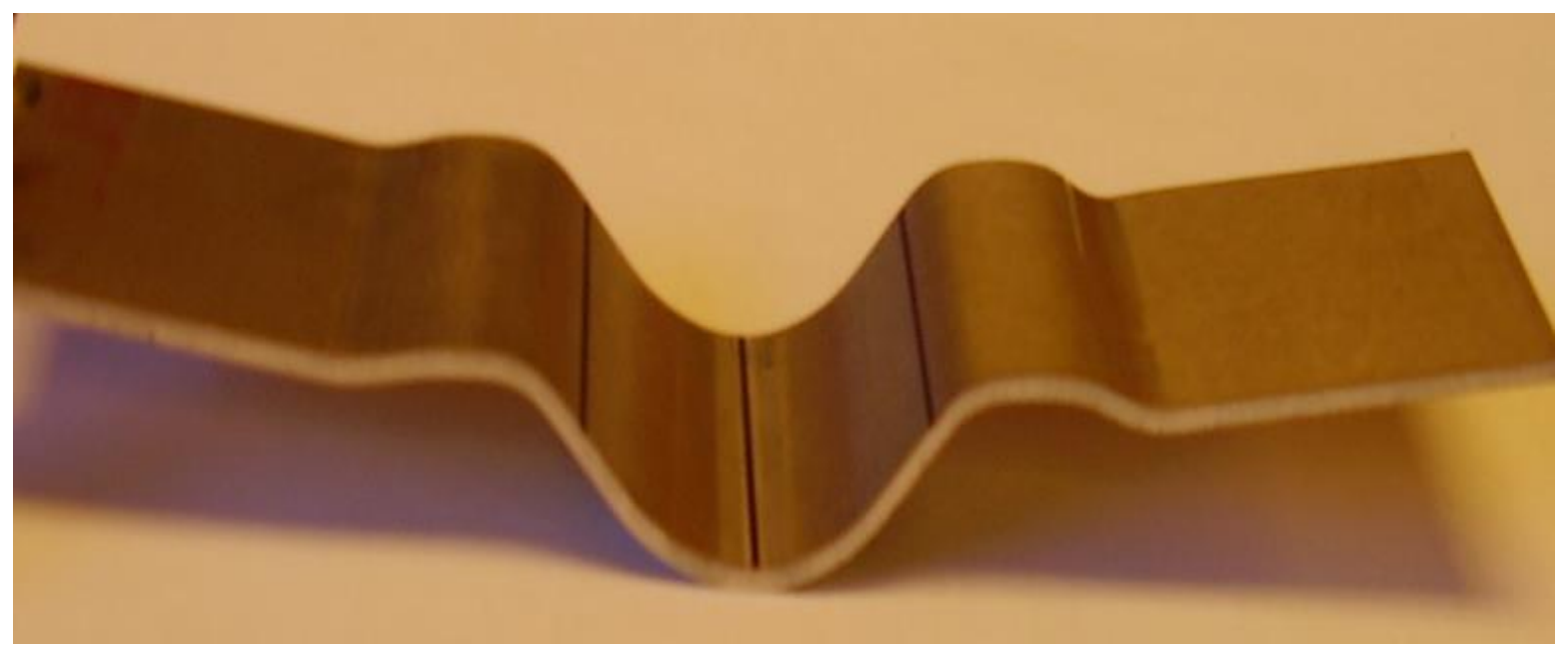

Figure 4.9 Welded Blank after Stretch forming

After the stretch forming process was completed, the blanks were removed to conduct post forming evaluation. The failure was observed to be due to the stress concentration rather than failure in the weld itself, showing the high quality of the weld as it stretched rather than undergo fracture. 
In order to evaluate the effect of process parameters on the formability, total depth of plunge at failure for different cases (Table 4.3) was measured. All formability results correlate well with the ductility properties reported in Table 4.2. Case Bi-A 2, with the highest ductility index, shows the highest formability of all other cases. The results reveal that high rotational velocity combined with slow weld velocity in FSW of bi-alloy Al 2024-T3/Al 7075-T6 structures will improve its stretch formability.

Table 4.3 Formability of FSW Al 2024-T3/Al 7076-T6 structures

\begin{tabular}{|l|l|l|l|l|}
\hline Case \# & $\begin{array}{l}\text { Rot. Vel. } \\
\text { RPM }\end{array}$ & $\begin{array}{l}\text { Weld Vel. } \\
\mathbf{m m} \text { /min. }\end{array}$ & $\begin{array}{l}\text { Ductility } \\
\text { Index } \\
\text { (\% Elong. })\end{array}$ & $\begin{array}{l}\text { Depth of } \\
\text { Plunge at } \\
\text { Failure (mm) }\end{array}$ \\
\hline Bi-A 1 & 1300 & 54.00 & 6.8 & 12.09 \\
\hline Bi-A 2 & 1300 & 92.10 & 12.3 & 16.37 \\
\hline Bi-A 3 & 1300 & 146.00 & 9.9 & 14.99 \\
\hline Bi-A 4 & 1300 & 194.00 & 7.2 & 9.14 \\
\hline Bi-A 5 & 1045 & 146.00 & 5.9 & 11.77 \\
\hline Bi-A 6 & 1045 & 92.10 & 12.5 & 15.45 \\
\hline Bi-A 7 & 1045 & 194.00 & 7.9 & 7.62 \\
\hline Bi-A 8 & 840 & 117.50 & 8.9 & 9.79 \\
\hline Bi-A 9 & 840 & 146.00 & 7.4 & 9.31 \\
\hline
\end{tabular}




\section{CHAPTER 5: CONCLUSIONS}

- Hybrid Manufacturing (HM) technology for net-shape production of monolithic structures for the transportation industry is explored.

- The developed technology combines FSW and stretch forming in order to tailor the properties of the preform to provide a net-shape monolithic structure.

- Obtained results provide an understanding of the effects of the major process parameters in $\mathrm{HM}$ for establishing successful monolithic structures that satisfy design requirements and product service conditions.

- In general, high tool rotational velocity combined with slow welding velocity in FSW; enhance stretch formability of the produced monolithic structure.

- The results are organized in process maps that define the process operating conditions that result in reasonable monolithic structure properties.

- Future studies are recommended to investigate the feasibility of the presented HM technology to monolithic structures with more complex geometry using deep drawing processes. 


\section{References}

1. Lauwers, B., Klocke, F., Klink, A., Tekkaya, A.E., Neugebauer, R., Mcintosh, D., “Hybrid processes in manufacturing," CIRP Annals - Manufacturing Technology, Vol. 63, No. 2, pp. $561-583,2014$.

2. El-Gizawy, A. S., Khasawneh F. A., Bogis H., "Drilling Process Design for Hybrid Structures of Polymer Composites over Titanium Alloy”, J. Material Sci. Eng., Vol. 5, doi:10.4172/21690022.1000243, 2016.

3. El-Gizawy, A. S., Chitti Babu S., and Bogis H, "An Integrated Modeling Approach for Management of Process-Induced Properties in Friction Stir Welding Processes,” J. of Appl. Mech. Eng., Vol. 5, doi:10.4172/2168-9873.100019, 2016.

4. Thomas, W. M., Nicholas, E. D., Needham, J.C., Murch, M. G., Templesmith, P., Dawes, C. J., "Friction Stir Welding," International Patent Application No. PCT/GB92102203 and Great Britain Patent Application No. 9125978.8, 1991.

5. Mishra, R. S., "Friction Stir Processing Technologies”, Advanced Mater. \& Processes: pp. 4346, 2003.

6. Mishra, R.S., Ma, Z.Y., "Friction stir welding and processing”, Mater. Science and Eng., Vol. 50, pp. 1-78, 2005.

7. Nandan, R., DebRoy, T., and Bhadeshia, H., "Recent advances in friction-stir welding Process, weldment structure and properties," Progress in Mater. Science, Vol. 53, No. 6, pp. 980-1023, 2008. 
8. Tang, W., Guo, X., McClure, J.C., Murr, L.E., Nunes, A., "Heat input and temperature distribution in friction stir welding," J. of Mater. Processing and Manuf. Science, Vol. 7, No. 2, pp. 163-172, 1998.

9. x Heurtier, P., Jones, M.J., Desrayaud, C., Driver, J.H., Montheillet, F., Allehaux, D., "Mechanical and thermal modeling of Friction Stir Welding," J. of Mater. Processing Tech., Vol. 171, pp. 348-357, 2006.

10. x Palm, F., Hennebohle, U., Erofeev, V., Earpuchin, E., Zaitzev, O., "Improved verification of FSW-process modeling relating to the origin of material plasticity," Proceedings of Fifth International Symposium of Friction Stir Welding, TWI Ltd, Metz, France, 2004.

11. Ulysse, P. "Three dimensional modeling of the friction stir welding process," Int. J. Mach. Tools Manufacture, Vol. 42, No. 14, pp. 1549-1557, 2002.

12. Askari, A., Silling, S., London, B., Mahoney, M., "Modeling and analysis of friction stir welding processing," K.V. Jata, et al (Eds.) Friction Stir Welding and Processing, TMS, Warrendale, PA, pp. 43-54, 2001.

13. Padmanaban, R., Ratna, V., and Balusamy, V., "Numerical Simulation of Temperature Distribution and Material Flow During Friction Stir Welding of Dissimilar Aluminum Alloys,” Procedia Engineering, Vol. 97, pp. 854 - 863, 2014.

14. Kesharwani, R.K., Panda, S.K., Pal, S.K., "Multi Objective Optimization of Friction Stir Welding Parameters for Joining of Two Dissimilar Thin Aluminum Sheets," Procedia Materials Science, Vol. 6, pp. 178 - 187, 2014.

15. Chao, Y. J., Wang, Y., Miller, K. W., "Effect of Friction Stir Welding on Dynamic Properties of AA2024-T3 and AA7075-T7351,” Welding Research Supplement, pp. 196-200, 2001. 
16. Cavaliere, P., Nobile, R., Panella, F.W., Squillace, A., "Mechanical and Microstructural Behavior of 2024-7075 Aluminum Alloy Sheets Joined by Friction Stir Welding," Int. J. of Machine Tools \& Manuf., Vol. 46, No. 6, pp. 588-594, 2006.

17. Cavaliere, P., Cerri, E., Squillace, A., "Mechanical Response of 2024-7075 Aluminum Alloys Joined by Friction Stir Welding,” J. of Materials Science, Vol. 40, No. 14, pp. 3669-3676, 2005.

18. Kimapong, K., Watanabe, T., "Friction Stir Welding of Aluminum Alloy to Steel," Welding Journal, Vol. 83, pp. 277-282, 2004.

19. Zhu, X.K., Chao, Y.J., "Numerical Simulation of Transient Temperature and Residual Stresses in Friction Stir Welding of 304L Stainless Steel,” J. of Materials Processing Tech., Vol. 146, No. 2, pp. 263-272, 2004.

20. Uzun, H., Donne, C.D., Argagnotto, A., Ghidini, T., Gambaro, C., "Friction Stir Welding of Dissimilar Al 6013-T4 to X5CrNi18-10 Stainless Steel,” Materials and Design, Vol. 26, No. 1, pp. 41-46, 2005.

21. Baumann, J.A., Lederich, R.J., Bolser, D.R., Talwar, R., "Property Characterization of 2024A1/7075Al Bi-Alloy Friction Stir Welded Joints," Friction Stir Welding and Processing III, pp. 199-207, 2003.

22. Ouyang, J.H., Kovacevic, R., "Material Flow and Microstructure in the Friction Stir Butt Welds of the Same and Dissimilar Aluminum Alloys," J. of Materials Eng. \& Perf., Vol. 11, No. 1, pp. 51-63, 2002.

23. Larsoon, H., Karlsson, L., Stoltz, S., and Bergqvist, E.L., Second International Symposium on Friction Stir Welding, Gotherburg, Sweden, 2000.

24. Schey, J.A., Introduction to Manufacturing Processes, 3rd edition, New York: McGraw-Hill, 
pp. 397-402, 2000.

25. Chan, L.C., Chan, S.M., Cheng, C.H., Lee, T.C., "Formability and Weld Zone Analysis of Tailored-Welded Blanks for Various Thickness Ratios,” J. Eng. Mater. and Techno., ASME, Vol. 127, 179-185, 2005.

26. ASTM, Annual Book of ASTM Standards, Vol. 02.02, 1999, p394-404.

27. Surendra Chitti Babu, A. Sherif El-Gizawy, “An Integrated Virtual Model for Characterization and Management of Process-induced Damage in Sheet Forming Processes", Proceedings,4th CIRP Int. Seminar On Intelligent Computation in Mfg. Eng., Naples, Italy, June, 2004, 321-326

28. Bolboacă, S.D.; Jäntschi, L. Design of Experiments: Useful Orthogonal Arrays for Number of Experiments from 4 to 16. Entropy 2007, 9, 198-232.

29. J. M. Trogolo, "Evaluation of Tailored Welded Blanks through Technical Cost Modeling", SAE \#980446, 1998.

30. L. Rui, W. Ya-Jun, L. Zhe, Z. Wei, "Expert System Based on Fuzzy Neural Network for the Optimal Control of the Blank Holder Force", Shanghay Jiaotong Daxue Xuebao, 35, n 3, Mar. 2001, 411-415. 